
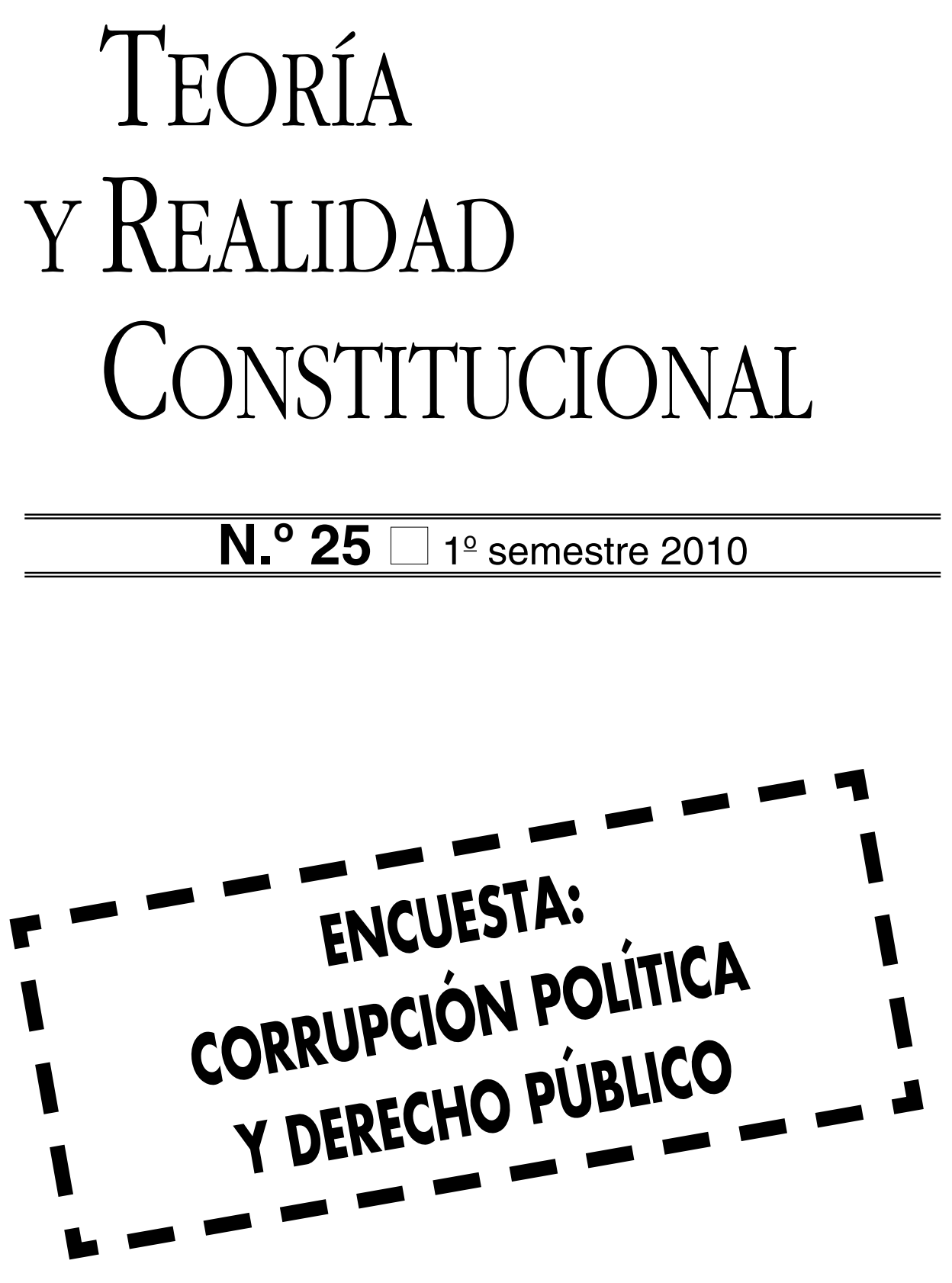


\title{
LAS CARTAS AUTONÓMICAS DE CUBA Y PUERTO RICO: PRIMER ANTECEDENTE DEL ESTADO AUTONÓMICO
}

MARÍA NÚÑEZ MARTÍNEZ

Profesora Colaboradora de Derecho Constitucional

UNED

\author{
SUMARIO \\ I. Cuba y Puerto Rico en el constituciona- \\ lismo histórico español. \\ II. La Ley de bases de 1895. \\ III. Las cartas autonómicas.
}

\section{CUBA Y PUERTO RICO EN EL CONSTITUCIONALISMO HISTÓRICO ESPAÑOL.}

La primera vez que se convoca a representantes de las islas antillanas a Cortes españolas es para la Junta de Bayona ${ }^{1}$, donde se reservan seis escaños para los territorios americanos, aunque no acudió a dicha llamada el único representante caribeño, el Marqués de San Felipe y Santiago por La Habana. Aunque la actuación de las Juntas de Bayona no tuvieron carácter constituyente y el propio Estatuto tuvo nula vigencia tanto en España como en los territorios americanos, sí cabe resaltar su importancia por considerarse en lo que se refiere a los territorios americanos un precedente de lo que acaecería en Cádiz poco tiempo después.

En la Carta Otorgada, el Título X del texto se dedica íntegramente a las posesiones españolas de ultramar "De los reinos y provincias españolas de América y Asia".

En el citado título, se proclaman los principios de carácter económico en los artículos 87 a 91 y los referentes a los principios de participación política

1 La convocatoria se publicó en la Gazeta de Madrid el 25 de mayo de 1808. 
y representación en los artículos 91 a 96. Así en el artículo 87 se lleva a cabo una proclamación general de igualdad de derechos entre los territorios metropolitanos y los de ultramar "Los reinos y provincias españolas de América y Asía, gozarán de los mismos derechos que la metrópoli, y en los artículos $88^{2}$ y $89^{3}$ se reconocía la libertad de comercio e industria dentro de los límites del Imperio Español, ${ }^{4}$ impidiéndose igualmente los privilegios y monopolios de importación y exportación (art. 90). ${ }^{5}$ Así mismo, en la importante tarea de codificación que intentó emprender el gobierno de la nueva casa reinante, claramente inspirada en la experiencia napoleónica en Francia, proclamó la igualdad de códigos para los territorios españoles y americanos, "Las Españas $y$ las Indias se gobernarán por un solo Código de Leyes civiles y criminales, ${ }^{6}$ "Habrá un solo código de comercio para España e Indias." "

Es igualmente en este texto, donde se concede por primera vez representación permanente en las Cortes y ante el gobierno a diputados de los diferentes reinos ultramarinos. La representación correspondiente los reinos y provincias de ultramar es de 22 diputados, de los que uno correspondía a la Isla de Cuba y otro a la de Puerto Rico.

Sin embargo, el texto de Bayona no dejó de ser anecdótico para el continente americano, ya que no tuvo vigencia alguna en esos reinos, que incluso se opusieron denodadamente al igual que la península a la ocupación francesa del trono de España. A este respecto, cabe destacar la decidida actuación de los Cabildos americanos, que o bien se apresuraron al reconocimiento de la Junta Central Española resistente a la invasión francesa, o bien por el hecho de ya estar inmersos en un proceso secesionista del territorio metropolitano se limitaron a no reconocer a la nueva realidad política española. En el caso de los territorios americanos más próximos a la península, caso de Cuba y Puerto Rico, que contaban con una información más fluida de los acontecimientos españoles, el rechazo fue total y con un carácter similar al producido en la propia metrópoli, así, en la isla de Cuba, la reacción negativa ante la entronización de José I fue total, llegando a ahorcar al emisario del mismo que con el fin de conseguir la sumisión de la isla a la nueva casa reinante había arribado a la provincia. Destaca la actuación del Cabildo habanero, que a propuesta de Francisco Arango Porteño reconocía la Junta Española, ofreciendo

2 "Será libre en dichos reinos y provincias toda especie de cultivo e industria". Artículo 88 del Estatuto de Bayona de 1808.

3 "Se permitirá el comercio recíproco entre los reinos y provincias entre sí y con la metrópoli". Artículo 89 del Estatuto de Bayona de 1808.

4 Sin embargo, es de resaltar la actitud de algunos representantes peninsulares en contra del desarrollo industrial en América, así cabe destacar la intervención del representante por Cataluña, D. José Garriga, partidario del proteccionismo y contrario al libre comercio, a favor de su región, como zona amenazada por el desarrollo industrial americano, en Sanz Cid." La Constitución de Bayona».Ed Reus. Madrid, 1992. pág. 137.

5 "No podrá concederse privilegio alguno particular de exportación o importación en dichos reinos y provincias". Artículo 90 del Estatuto de Bayona de 1808.

6 Artículo 96 del Estatuto de Bayona de 1808.

7 Artículo 113 del Estatuto de Bayona de 1808. 
lealtad al Rey Fernando VII, así como la negativa del Marqués de San Felipe y Santiago a participar en la Asamblea de Notables convocada en la ciudad de Bayona.

Rechazada en Cuba y Puerto Rico, como en los restantes territorios americanos la legitimidad de la casa de Bonaparte en la Corona de España, sólo le quedaban dos opciones, la separación del Imperio Español, mediante la proclamación de la independencia, como aconteciera en la mayoría de los territorios de "Tierra firme" o acudir a la convocatoria de las Cortes de España. ${ }^{8}$

La opción independentista, además de en los países indicados en nota anterior, tuvo especial importancia en la isla de Puerto Rico, debido a factores de proximidad geográfica con Venezuela, y donde un amplio sector de la sociedad boricua seguía con especial interés los acontecimientos de Venezuela, donde el país se dotaba de un texto constitucional. A este respecto, existe constancia de la comunicación existente entre los cabildos insulares, especialmente el de San Juan y los de Caracas, Cartagena y Coro, que demandaban ayuda en su deseo emancipador.'

Sin embargo, el proceso de acercamiento entre los independentistas de Nueva Granada y las élites criollas de la isla se truncó debido a dos aspectos fundamentales:

$\left.1^{\circ}\right)$ La decidida intervención de la máxima autoridad de la isla, el Gobernador Don Salvador Meléndez, que encarceló a los emisarios continentales, consiguió la destitución de varios miembros del Cabildo de San Juan y presionó al Obispo Arizmendi para que interrumpiera sus contactos con los eclesiásticos de Caracas, informando al Consejo de Regencia sobre las actividades del citado prelado y de otras personalidades de la isla. ${ }^{10}$

$2^{\circ}$ ) Las contradicciones existentes entre los grandes hacendados y comerciantes por un lado, y por otro los pequeños propietarios de fincas existentes en virtud de la reducida extensión del territorio, ${ }^{11}$ así como dueños de pequeños comercios y sectores profesionales, mayoritarios cada sector en los diferentes cabildos. Los primeros, aunque partidarios de una mayor apertura de mercados y del libre cambio que impedía la rígida organización imperial española, estaban recelosos de cualquier modificación que pudiera alterar la estructura social asentada en el esclavismo; en este sentido, el proceso inde-

8 Mediante el Real Decreto de 14 de febrero 1810, dado por el Consejo de Regencia, se hacía la convocatoria a las Cortes del Reino, que incluía en su llamada a representantes de los territorios españoles de ultramar.

9 Véase PICÓ F., Historia General de Puerto Rico“ pág. 127, San Juan de Puerto Rico 1988. También en CRUZ MONCLOVA, L., "Historia de Puerto Rico, siglo XIX. Editorial Universidad de Río Piedras. Puerto Rico. 1984 .págs 34-41.

10 PICÓ, F., Y CRUZ MONCLOVA, L, ops. cit..

11 Desde 1765, fecha de la llegada del Gobernador O’Reilly, se había producido la llegada de importantes contingentes de colonos españoles, lo que había posibilitado un nuevo reparto de tierras; no obstante, de forma paralela se había producido un incremento en la importación de esclavos y gran auge de los ingenios azucareros. 
pendentista y constituyente que se estaba produciendo en el continente, fuertemente influenciado por el liberalismo, podía significar el fin de esa situación, así mismo, el anticlericalismo y laicismo que llevaba aparejado el proceso independentista, como indica Picó impresionaban mal a unos sectores que se identificaban a sí mismos como religiosos. ${ }^{12}$ Los segundos, salvo un reducido grupo decididamente liberal, no contaban con suficiente peso económico y social, ni conocían suficientemente el desarrollo ideológico que se abría con los nuevos procesos constituyentes.

Ello, no obsta, para que tanto en Puerto Rico como en Cuba se produjeran algunos conatos de emancipación entre las élites ilustradas, así debemos destacar el proyecto llevado a cabo por los cubanos Don Ramón de la Luz Silveira y el Doctor Joaquín Infante, que llegó incluso a elaborar un proyecto de Constitución. En Puerto Rico se produjo una actitud similar, que se manifestó tanto en la tibieza antes indicada en la relación con los independentistas venezolanos, como en los acuerdos aprobados por los diferentes cabildos para sus representantes. ${ }^{13}$

La opción, de participar en las Cortes de Cádiz, que desde su convocatoria tuvo en las mentes americanas un carácter constituyente se decantó como la única opción posible para los habitantes de las islas caribeñas Sin embargo, valga como ejemplo de las tensiones existentes en la sociedad, la respuesta última dada por el Cabildo de San Juan al de Cartagena y que significaba el fin de la colaboración con los independentistas de Nueva Granada, "Fluctuando en este bajel de confusiones y conceptuando estos extremos como los escollos de Scilla y Caribdis, guardaba este Cabildo un profundo silencio; pero la Providencia por un efecto de sus inescrutables juicios nos presentó en medio de estas tribulaciones un aquilón que disipase las nubes y un arco iris que anunciase la paz y serenidad en nuestros ánimos para caminar sin tropiezos ni peligros. Sí señores llegó la plausible noticia de que la Regencia, mostrando su paternal solicitud y deseando unirnos estrechamente con la Metrópoli se dio prisa a celebrar las extraordinarias Cortes Generales para consolidar el bien y la prosperidad de todos." ${ }^{14}$

La participación americana en las constituyentes tuvo una significación muy activa, así representando apenas un veinte por ciento del total durante los casi tres años que duraron las sesiones llegaron a representar más de un

12 Véase PICÓ F., ob ant cit pág. 128.

13 Cabe destacar a este respecto, el acuerdo del Cabildo de San Germán respecto al reconocimiento de la Junta Suprema, que reproducimos a continuación: "Primeramente debe protestar que esta Villa reconoce y se sujeta a dicha Suprema Junta Central abora y en todo tiempo que gobierne en nombre de Nuestro muy amado, Augusto, y Dignísimo Rey el Señor don Fernando Séptimo y su Dinastía; pero si por Disposición Divina ( y lo que Dios no permita) se destruyese esta y perdiese la Peninsula de España, quede independiente esta Isla y en libre arbitrio de elegir el mejor medio de la conservación y subsistencia de sus habitantes en paz y religión Christiana"ob, ant, cit.

14 Actas del Cabildo de San Juan. Febrero 1810. 
tercio de la Mesa de la Cámara y sus diputados se alinearon en las filas más progresistas de las mismas.

La isla de Cuba a quién correspondía una representación de dos diputados en las Cortes Extraordinarias, designó para esta función a Don Andrés de Jáuregui por la ciudad de La Habana y a Don Juan Bernardo O’Gaban por Santiago de Cuba, contando como diputados suplentes al Marqués de San Felipe y a Don Joaquín de Santa Cruz. La isla de Puerto Rico contó como representante a Don Ramón Power.

De entre los diversos proyectos que recibieron los diputados americanos, podemos destacar dos memoranda, originarios de Cuba, uno remitido por el Real Consulado de Agricultura y Comercio, obra de Francisco de Arango y Parreño, en el que había colaborado Antonio del Valle Hernández, y otro redactado por el Presbítero José Agustín Caballero, así como los referentes a la abolición del tráfico de esclavos, presentados por los mexicanos José Miguel Guridi y Alcocer.

Ambos proyectos son representativos de la conformación de la sociedad cubana de la época, así el primero puede considerarse exponente de los intereses del sector de grandes hacendados, incidiendo fundamentalmente en los aspectos económicos que deberían derivarse de texto constitucional, por el contrario, el segundo propio del constitucionalismo liberal mas avanzado, incidiendo en los aspectos políticos, e incluso se decanta por un cierto carácter democrático, aunque defienda el sufragio censitario.

En el Proyecto de Arango y Parreño ${ }^{15}$ pueden destacarse los siguientes aspectos: $1^{\circ}$ ) Economía: Tiene su base en el "Discurso sobre la Agricultura de La Habana y medios de fomentarla", defendiendo posturas de carácter fisiócrata. Defiende el libre comercio, tanto con España como con otros mercados, aunque no relaciona prácticamente esta libertad económica con otra de carácter político, ya que el país no quería comprometer su privilegiada situación geográfica entre Nueva España, la Península y otros territorios de la América Española, necesitando especialmente la parte que le correspondía de las remesa de la primera. Incide en el carácter intocable de la propiedad y en la disminución de impuestos. Propone la creación de una Intendencia de Hacienda en la isla que tenga capacidad de decisión sobre los recursos recaudados en la misma, de manera que los mismos se reinviertan en Cuba, asî como que la inversión en obras de infraestructura tenga carácter público. Instituye el Consejo Provincial al que otorga funciones más económicas que políticas, de tal forma, que las actividades económicas producidas en Cuba fueran reguladas por instituciones cubanas. $2^{\circ}$ ) Política: Su innovación más importante es la creación de un Consejo Provincial, compuesto por veinte miembros, diez correspondientes a La Habana y otros diez al resto de la isla. Las funciones del Consejo, entre las que cabe destacar especialmente las re-

15 El texto íntegro del Proyecto se encuentra en los Archivos del Congreso de los Estados Unidos; el presente trabajo tiene su base en la versión DE CARRERAS J. A., Historia del Estado y el Derecho en Cuba, págs. 151 y ss, Pueblo y Educación, La Habana, 1985. 
ferentes a economía ya indicadas en el punto anterior, se refieren casi exclusivamente a aspectos administrativos y civiles. El proyecto no entra en la organización política a fondo, dejando intacta la estructura militar, a cuya cabeza está el Capitán General, cuyos poderes son similares, salvo en lo indicado en el campo de la economía, al período precedente. Aunque propone un control sobre los funcionarios y la administración de la isla, no entra en el campo de la Administración de Justicia.

En el Proyecto de José Agustín Caballero, pueden destacarse los siguientes aspectos: $1^{\circ}$ ) Economía: No plantea grandes diferencias con respecto al texto de Arango y Parreño, aunque defiende la necesidad de diversificar la misma, de tal forma, que no todo el peso de la misma recaiga sobre el campo. A este respecto propone el desarrollo de la actividad pesquera y de la industria naval. En el mismo sentido que el memorandum anteriormente citado plantea la necesidad de mejorar la infraestructura vial de la isla mediante la reinversión Cuba de los beneficios generados por ésta. $2^{\circ}$ ) Política: Es en este aspecto en el que manifiesta mayor número de innovaciones. En los planteamientos del Presbítero José Agustín Caballero se percibe la influencia de la ilustración, especialmente de Montesquieu, por lo que puede ubicarse dentro de un cierto liberalismo de carácter aristocrático.

El sistema de organización política que plantea tiene su base en una cierta descentralización respecto a la metrópoli y en la división de poderes aunque no de carácter radical. ${ }^{16} 1$. Poder Ejecutivo. Reside en el Capitán General que es el Rey en la isla, sus funciones no están sujetas a control por parte de la Cámara legislativa de la provincia. Las disposiciones provinciales emanadas por la Cámara Legislativa provincial necesitaban la aprobación del Gobernador, así mismo las decisiones representante real no podían discutirse en la citada asamblea. 2. Poder legislativo: Crea las Cortes Provinciales de la isla de Cuba, que puede legislar sobre aquellos aspectos que afecten a Cuba y que no lo haya sido hecho por las Cortes de España. Reivindica la necesidad de existencia de Leyes especiales para Cuba que hayan sido redactadas por los propios cubanos. Asume algunas funciones de carácter económico, en lo referente a la Intendencia, la Junta Real de Hacienda, Tribunales de Cuentas y otras de índole menor relacionadas con los diversos sectores productivos de la isla, así como de imposición de tributos etc. La Asamblea es representativa de la población de la isla, estando compuesta por sesenta diputados, correspondiendo treinta a la zona occidental (La Habana), nueve a Santiago de Cuba, seis a Puerto Príncipe, y tres a Trinidad, San Juan de los Remedios, Sancti Espíritu, Villa Clara y Matanza, respectivamente. La Asamblea constaría de un Presidente electo de entre sus miembros, así como de otros miembros responsables de las diversas áreas de trabajo. Se establece el sufragio restrictivo, con carácter censitario y reservado a propietarios de determinadas rentas y

16 BIZCARRONDO M Y ELORZA A., "Cuba/ España. El dilema autonomista, 1878-1898.ed. Colibrí Madrid. 2001 
bienes en la isla. La edad para ejercer el sufragio activo se fija en veinticinco años. 3. La Justicia. Propone como cambio más importante la creación de la figura del Corregidor, que asumiría parte de las funciones judiciales y lo referente a la Policía Criminal. El Gobernador, como Capitán General conserva las atribuciones en lo referente al Juzgado Militar ${ }^{17}$. Respecto a otras propuestas, cabe destacar la del diputado Ramón Power, representante por Puerto Rico, que sería uno de los más activos representantes americanos en las primeras constituyentes españolas, llegando a desempeñar el cargo de Vicepresidente de la Cámara. ${ }^{18}$

Sobre la base de las diversas recomendaciones que se darán al diputado Power ${ }^{19}$ al emprender su viaje a España, ya nos hemos referido anteriormente al analizar la situación de los Cabildos y la isla en el momento de producirse la invasión napoleónica; es por ello, que nos limitaremos a señalar los aspectos básicos contenidos en las instrucciones producidas en los acuerdos de los Cabildos de San Juan, Coamo, San Germán y Aguada, que pueden resumirse en las aspiraciones de libre comercio y libre entrada de capitales. ${ }^{20}$

El rápido proceso de emancipación de la inmensa mayoría de los territorios americanos de la Corona española, salvo el caso de las islas de Cuba y Puerto Rico, que seguirán formando parte de la misma hasta 1898, tiene como consecuencia, que los textos constitucionales posteriores a la Constitución de Cádiz, no dediquen prácticamente parte de su articulado a los territorios que todavía forman parte del Estado español, remitiéndose en todo caso a una ley posterior que regularía el problema.

La vuelta de Fernando VII al trono de España y el fin del Estado de Derecho en 1814, supuso un duro golpe para los territorios caribeños, así junto a la derogación de los derechos y libertades proclamados en el texto gaditano, se suprimiría la Diputación Provincial y se despojaría a los criollos de la ciudadanía española, desapareciendo la consideración de provincia para las islas, aunque a diferencia del periodo anterior del Antiguo Régimen, se adoptarán

17 Véase, CARRERAS J. A., "Historia del Estado y el Derecho en Cuba":ed .Ministerio de Educación Superior. La Habana, 1981, págs. 154 y ss.

18 La elección de Ramón Power, se llevó a cabo en solemne sesión pública el 16 de agosto de 1809. De la importancia que tuvo para Puerto Rico contar con representación en las Cortes de Cádiz, se muestran las palabras del Obispo de San Juan, que llegó a entregar al diputado en la sesión de designación su propio anillo pastoral. En FRAGA IRIBARNE, M., Las Constituciones de Puerto Rico, Cultura Hispánica. Madrid. 1953.

19 Cabe destacar que Ramón Power fue uno de los diputados americanos más activos en la defensa de la igualdad de derechos entre los naturales de la península y los territorios americanos, acción que desarrolló en conjunción con los representantes Mejía Lequerica de Nueva Granada y Morales Duárez por Perú, así mismo destacó en su defensa de un sistema electoral mas generoso para los territorios americanos, en cumplimiento del mandato de los Cabildos de Santa Fe, La Habana y Nueva España.

20 En todo caso, sólo podemos referirnos a Proyectos, cuando se sustentan en acuerdos de los cabildos y reflejados en las actas correspondientes, pues el proceso de sustitución de los representantes americanos por otros originarios de dichos territorios, pero residentes en España, impide delimitar si se trata de proyectos personales o institucionales. 
medidas liberalizadoras en el terreno económico, ${ }^{21}$ que posibilitaban el tráfico mercantil de las islas con la península y las naciones extranjeras amigas.

Durante el denominado "Trienio Liberal", las islas de Cuba y Puerto Rico, recuperarían el status previsto en el texto constitucional de 1812. Destaca en este periodo el Proyecto presentado ante las Cortes por los representantes cubanos Félix Varela y Leonardo Santos Suárez, al que se uniría el representante por la Isla de Puerto Rico, José María Quiñones. ${ }^{22}$ El citado proyecto tenía como objetivo reformar el gobierno de las provincias de ultramar, de tal forma, que se redujeran las atribuciones del Gobernador, mediante el reforzamiento de las de la Diputación Provincial, que controlaría en determinados aspectos al Gobernador y estaría representada ante el Rey y las Cortes, pudiendo entre otras cosas elaborar su propio presupuesto y el de la provincia.

El Proyecto, en cierto aspecto, revela una de las principales contradicciones del primer Estado Liberal, como es la "proclamación de igualdad en una sociedad de desiguales", de tal forma, que los principios proclamados en Cádiz son de difícil aplicación en una sociedad de carácter colonial, claramente diferenciada de la existente en la España peninsular, así como indica Trías Monge, ${ }^{23}$ el proyecto Varela-Quiñones revela bastante sobre la época y los hombres que lo producen. Es índice, en primer término, de la insatisfacción del naciente pensamiento liberal en las colonias con la solución que al problema de Ultramar proponía la Constitución de Cádiz. Aun las beneficiosas reformas que ésta entrañaba al régimen absolutista no mejoraban en grado suficiente la condición política de los colonos. La representación en Cortes, la alegada libertad de expresión, los ayuntamientos electivos, el establecimiento de la Diputación Provincial, la condición, en suma, de parte integrante de la monarquía, no bastaban para proteger adecuadamente a la comunidad contra los desmanes de gobernadores despóticos, ni le aseguraba la adopción de leyes justas. De ahí, que se pida más.

El Proyecto supone un hito importante en la historia del constitucionalismo español, en cuanto significa, o es en todo caso, el origen del único aspecto originario del mismo, la conformación de entidades autonómicas de carácter no sólo administrativas, sino también políticas, dentro del Estado, modelo cercano en la práctica al esquema federal, ya existente en la época, pero jurídicamente muy diferenciado de éste ${ }^{24}$. El Proyecto, como indica Cruz Monclava, ${ }^{25}$ representa una nueva evolución de la política colonial: el tránsito del sistema asimilista al de tipo autonomista, así como el Decreto de

21 Cédula de Gracias de 1815

22 Véase MEDARDO VITIER., "Las ideas en Cuba, Trópico. La Habana, 1938.

23 TRÍAS MONGE J., Historia Constitucional de Puerto Rico. vol I, Universidad de Río Piedras. Puerto Rico, 1980.

24 Dicho modelo no se desarrollará hasta las Cartas Autonómicas de 1898, de nula vigencia prácticamente, y no se alcanzará hasta el denominado Estado Integral de la Segunda República y su posterior consolidación en la Constitución española de 1978.

25 CRUZ MONCLAVA L.; Historia de Puerto Rico T I. pág. 196 Ed. Universidad de Río Piedras. Puerto Rico, 1952. 
la Junta Suprema de 22 de enero de 1809 había representado el tránsito del sistema administrativo al de tipo asimilista; sin embargo, el proyecto, como ocurrirá con leyes especiales posteriormente anunciadas en los siguientes textos constitucionales españoles no será aprobado. La vuelta al absolutismo pondrá punto final al primer proceso autonómico para los territorios americanos dependientes todavía de la Corona española, ${ }^{26}$ así, el Gobierno absolutista de Fernando VII, proclamará la Real Orden de 28 de mayo de 1825, concediendo facultades extraordinarias y discrecionales a los Capitanes Generales como Gobernadores de "plaza sitiada", y creando una Comisión Ejecutiva y Permanente para toda clase de delitos y sospechas de carácter político, ${ }^{27}$ que pondría fin no sólo a la posible autonomía de las islas, sino que establecía un régimen dictatorial, ${ }^{28}$ que en lo fundamental no sería variado en los siguientes años por los gobiernos liberales. ${ }^{29}$

El Estatuto Real de 1834 no contiene referencia alguna a los territorios americanos, la posterior vigencia de la Constitución de 1812 abrió de nuevo el camino a la representación americana, pero la ley de 18 de abril de 1837, declaró que las posesiones de ultramar serían gobernadas por Leyes especiales, lo que de nuevo quitaba la representación a las islas caribeñas, aunque esta vez no como consecuencia del absolutismo imperante, sino traído por los liberales que ahora gobernaban en España. A este respecto, cabe destacar la actitud de los representantes cubanos elegidos en las Cortes de 1836, que presentaron una dura protesta en el Parlamento, que se oponía la Ley de 1837; ${ }^{30}$ no obstante, el sector liberal integrante de las Cortes, que formó parte de la comisión de reforma de la Constitución en asuntos de Ultramar, ${ }^{31}$ no se inclinó ante las peticiones caribeñas, en virtud del recelo que se tenía respecto a las intenciones de los americanos, que presumían eran independentistas, actitud que puede considerarse consecuencia directa de la cercana emancipación de los restantes territorios de la América Española ${ }^{32}$ valga como ejemplo la in-

26 La batalla de Ayacucho de 9 de diciembre de 1824 marcaría el final de la presencia española en el continente suramericano.

27 Véase, FRAGA IRIBARNE M; "Las constituciones de Cuba", pág. XI. Ediciones de Cultura hispánica, Madrid, 1952.

28 Se emplea el término dictatorial por diferenciar la situación de la previa al Estado constitucional del Antiguo Régimen, pues ahora el poder no estaba sujeto al control de las Chancillerías y Audiencias y el juicio de residencia había quedado reducido a una mera fórmula, por otra parte, el Consejo de Indias se extinguirá definitivamente en 1834

29 Véase del mismo autor Las Constituciones de Puerto Rico, pág. 10. Ediciones de Cultura hispánica, Madrid, 1953.

30 Los diputados firmantes fueron: Juan Montalvo y Castillo, Francisco de Armas y José Antonio Saco.

31 Formaban parte de esta comisión, Agustín Argüelles, Vicente Cacho, Martín de los Heros, Antonio González, Manuel Joaquín Tarancón, Joaquín $M^{a}$ Ferrer, Mauricio Carlos Onís, Pedro Antonio Acuña, Manuel $\mathrm{M}^{\mathrm{a}}$ Acevedo, Jacinto Félix Doménech, Álvaro Gómez Pablo Torrens y Miralda, Antonio Flores Estrada, y Pío Laborda..En Información sobre Reformas de Cuba y Puerto Rico. T.I. pág. XXII.. Imprenta de Hallet y Breen.1867. Nueva York.

32 Actitud que se mantendría por la clase política española hasta bien avanzado el último tercio del siglo XIX. 
tervención en las Cortes de Agustín de Argüelles, al respecto "Si a la isla de Cuba se le daban derechos politicos ella se declararía independiente; los diputados de las provincias de Ultramar emplearian el elemento de libertad como medio de ilustración y romperían los lazos que la unian a la Metrópoli. ${ }^{33}$

De esta forma, la reforma de la Constitución de 1812, que acabaría en el texto de 1837, tampoco haría referencia a los territorios americanos, limitándose a proclamar en el texto, en su segundo artículo adicional, que "Las provincias de ultramar serán gobernadas por leyes especiales", reproducción exacta de lo manifestado en la anterior ley citada. ${ }^{34}$ Las razones esgrimidas por la Comisión citada, tienen su base, tanto en datos poblacionales de los territorios de ultramar, en los que la población no europea representaba la mitad de la misma, así como por la distancia de dichos territorios respecto a la metrópoli "Penetradas, pues las Comilones, por cuanto queda expuesto y más que pudiera añadirse, de que nuestras posesiones de América y Asia, ni por la distancia, a que se encuentran de la península, ni por la naturaleza de su población, ni por la diversidad de sus intereses materiales, puedan ser regidas por unas mismas leyes, han convenido de común acuerdo en proponer a las Cortes que desde luego declaren en sesión pública que : no siendo posible aplicar la Constitución que se adopte en la Península e Islas adyacentes a las provincias ultramarinas de América y Asia, serán éstas regidas y administradas por leyes especiales y análogas a su respectiva situación y circunstancias, y propias para bacer su felicidad, y que en consecuencia no tomarán asiento en las Cortes actuales Diputados por las expresadas provincias." 35

La Constitución de 1845 se limita de nuevo a reproducir lo proclamado al respecto en el texto de 1837, haciéndolo en el artículo adicional 80, así como el texto de la no promulgada de 1856, que repite la misma fórmula en el artículo 86, con la salvedad de que no lo hace en los artículos adicionales, sino que dedica el Título XIV: "Del Gobierno de las provincias de ultramar,",36 aunque éste sólo contenga un artículo.

Sin embargo, las Leyes especiales nunca llegaron a proclamarse, aunque sí se produjo un intento, mediante la creación de una comisión para el estudio de las mismas en diciembre de 1838, que pasó unos meses en Puerto Rico y Cuba, pero que no obtuvo resultados al respecto.

Las únicas leyes específicas que se producirán para estos territorios serán la R.O. de agosto de 1847, que se ocuparía de los Ayuntamientos y la R.O. de 1861, que creó un Consejo de Administración, con la función de órgano

33 En Información sobre Reformas de Cuba y Puerto Rico T.I. pág. XXIII.. Imprenta de Hallet y Breen.1867. Nueva York.

34 No obstante, el texto constitucional no establece diferencias en cuanto a nacionalidad entre los habitantes de ambos hemisferios, así el artículo 1.1. proclama "Son españoles: todas las personas nacidas en los dominios de España."

35 Informe de la citada Comisión, Palacio de las Cortes, 10 de febrero de 1837.

36 Una R.O. de 27 de marzo de 1857, prohibiría la utilización del término colonia para referirse a las posesiones ultramarinas. 
consultivo del gobierno y con funciones de Tribunal de lo Contencioso, que debía estar compuesto por originarios de las respectivas islas y ser electos por las mismas. Cabe destacar igualmente, el intento producido en 1865 , siendo Cánovas del Castillo, Ministro de Ultramar ${ }^{37}$ de formar una Junta de información, ${ }^{38}$ en la que había una nutrida representación caribeña, con el fin de elaborar las tan anunciadas Leyes Especiales. La Junta citada comenzó sus trabajos en Madrid, el 6 de noviembre de 1866, disolviéndose el 26 de abril de 1867 sin haber obtenido resultados positivos, posiblemente debido al clima de inestabilidad política existente tanto en España como en Cuba en aquel momento, así como por el hecho de que su principal mentor Cánovas había dejado de ser ministro, sucediéndole Alejandro de Castro. ${ }^{39}$

No obstante lo indicado, la labor de la Junta fue de suma importancia, en cuanto sirvió de cauce para plantear los graves problemas que afectaba a los territorios antillanos y las posibles soluciones a los mismos, evidentemente los resultados de aquella comisión no tuvieron ningún alcance práctico en cuanto a cambio de legislación se refiere, pues ni el último gobierno isabelino podía asumirlos, ni el parlamento español en fase de desintegración podía considerarlos; sin embargo, para las naciones caribeñas el resultado fallido fue muy importante, ya que como diría Francisco Quiñones, años más tarde, "aquello valió para despertar la conciencia de los puertorriqueños" ${ }^{40}$. De la importancia que tuvo la Junta para Cuba y Puerto Rico y de las expectativas que sobre la misma se tenían es prueba la siguiente expresión contenida en el informe de la misma, "Donde no existen instituciones cimentadas en la tradición y en el respeto de los pueblos; que vienen llenando aunque sea defectuosamente las necesidades generales que en su dia se estimaron perfectas y que si después han indicado la necesidad de reformas, ha sido por las lecciones de la experiencia, la modificación de las condiciones sociales o los adelantos de las ideas, se concibe muy bien que las reformas se hagan lentas y sucesivamente. La máquina gubernativa está montada y funcionando; sólo se trata de sustituir algunas de sus ruedas, mejorándolas... pero donde no existen instituciones de ninguna especie, donde en realidad no hay otra máquina de gobierno que la centralización de todos los poderes y las facultades discrecionales de una Autoridad omnimoda ¿ cómo puede concebirse la idea de reformas parciales?. Un edificio puede irse reparando por partes, una máquina que funciona puede recibir mejoras parciales, más donde no hay edi-

37 El Ministerio de Ultramar se creó mediante R.D. de 20 de mayo de 1863, estructurándose mediante ley orgánica el 23 de junio del mismo año.

38 La Junta de Información fue creada mediante el R.D. de 25 de noviembre de 1865; cabe destacar que. no menciona a los territorios españoles en Asía.

39 Véase al respecto, FRAGA IRIBARNE, M., "Las constituciones de Puerto Rico, op. cit., págs. 13 y ss.

40 NÚÑEZ RIVERO C., "Puerto Rico en el constitucionalismo histórico español”.Rv.A Distancia $n^{\circ}$ monográfico "1492-1992. España y América pág. 148. UNED. Madrid.1993.Véase, QUIÑONES F.M., Historia de los partidos reformista y conservador, pág. 27. Tipografía comercial, Mayagüez, 1889. 
ficio ni máquina, preciso es crear, edificar o establecer, porque mal puede reformarse lo que no existe.. ${ }^{41}$

De esta forma, los comisionados de Cuba y Puerto Rico no se limitaron a pedir la aplicación literal del texto constitucional español vigente, al que por otra parte, consideraban ya caduco, sino que en sus peticiones fueron más lejos, solicitando una Carta de Derechos muy superior a la reconocida en la Constitución española, que incluyera no sólo los derechos y libertades individuales, sino también los derechos de reunión, asociación, manifestación, prensa, habeas corpus etc.

Por otra parte, en el citado informe, plantean aunque no claramente, un auténtico gobierno parlamentario para las islas, en virtud de la reconversión de la Diputación Provincial en una verdadera Cámara Baja y la creación de una Junta Provincial, de tal forma, que la figura del Gobernador fuese similar a la de un Jefe de Estado constitucional y parlamentario, que no intervenía ni siquiera en la elaboración del presupuesto.

Se pedía igualmente el voto directo, en virtud de un diputado por 45.000 habitantes y ayuntamientos de carácter electivo.

En realidad, los miembros de la "Junta Informativa", eran conscientes de que no estaban proponiendo una reforma a la legislación vigente, sino un nuevo texto constitucional, así en el final del informe se llega a decir textualmente, “(...) Tal vez las islas de Cuba y Puerto Rico son los territorios más adecuados para plantear de momento un sistema liberal y completo de gobierno, por la misma razón que en ella no ha habido jamás ninguno que merezca ese nombre." ${ }^{42}$

Será la revolución de 1868, la que cambiará radicalmente el status de los territorios americanos de la Corona Española, así en el texto de 1869 volverá a otorgar representación en Cortes a los representantes cubanos y puertorriqueños; que se había perdido desde la Constitución de 1837. Así mismo, la Carta de 1869 significó un considerable adelanto en relación a los textos anteriores, en cuanto, que, en virtud de su artículo 108, las Cortes constituyentes se comprometían a reformar el "actual sistema de gobierno de las provincias de Ultramar, cuando hayan tomado asiento los diputados de Cuba o Puerto Rico, para hacer extensivos a las mismas, con las modificaciones que se creyeren necesarias, los derechos consignados en la Constitución.. ${ }^{43}$

41 NÚÑEZ RIVERO C., op. cit., págs. 147 y 148; véase el texto completo en CRUZ MONCLAVA, Historia de Puerto Rico, op. cit., pág. 147 y ss. Sobre la actuación de la Comisión, véanse TRIAS MONGE, Historia constitucional de Puerto Rico, op.cit., pág. 49 y ss.; igualmente, VARELA, F, Observaciones sobre la Constitución política de la Monarquia Española. ed. Universitaria de La Habana, 1994; más recientemente, DOMINGO ACEBRÓN, M.D.; DE LABRA R M. Cuba, Puerto Rico, Las Filipinas, Europa y Marruecos, en la España del Sexenio Democrático y la Restauración pág. 159 y ss. Consejo Superior de Investigaciones Científicas. Madrid, 2006.

42 NÚÑEZ RIVERO C., op. cit., pág. 148.

43 No obstante, es de destacar, que el texto no pudo tener vigencia en Cuba, en virtud de que en octubre de 1868, comenzaría una importante sublevación en la isla, que no acabaría hasta la Paz de Zanjón de 10 de febrero de 1878. Puerto Rico, aunque también conoció un estallido 
En el primer año de vigencia de la Constitución se creó una Comisión de Reformas, con el fin de desarrollar el citado artículo 108, presidida por Manuel Becerra, Ministro de Ultramar. ${ }^{44}$ Las conclusiones de la Comisión, que tenían como objetivo la proclamación de la Constitución en América ${ }^{45}$ recomendaba la aplicación del Título I del texto constitucional en Puerto Rico, ${ }^{46}$ lo que implicaba los siguientes aspectos: Reconocimiento de provincia española y parte integrante del territorio español; Reconocimiento de los derechos y libertades individuales (arts. 2 a 31). ${ }^{47}$

Así mismo, se recomendaba la confirmación de una Diputación Provincial, con ciertas atribuciones parlamentarias, separación de las gobernaciones militar y civil, eliminando las facultades discrecionales de los Gobernadores, ${ }^{48}$ que se pudieran diferenciar de las existentes en la Península. ${ }^{49}$

Aunque el informe reconocía la representación en Cortes de Puerto Rico y la elección a los ayuntamientos, restringía el derecho al voto, proclamado en el artículo 16 de la Constitución, que reconocía el sufragio universal masculino. El informe de la Comisión establecía el sufragio censitario para la isla, de tal forma, que sólo los contribuyentes de determinadas rentas podían ejercerlo.

Sin embargo, las recomendaciones de reforma no prosperarían, ${ }^{50}$ así como tampoco el Proyecto de Carta Autonómica preparado por Segismundo

revolucionario en septiembre de 1868, éste fue prontamente sofocado por las autoridades españolas, aplicando las mismas una política de reconciliación que posibilitó la incorporación de la isla al sistema político español y a contar con representantes en las Cortes.

44 Como se indica en la nota anterior, los trabajos de la Comisión, sólo se referían a Puerto Rico.

45 La Constitución no se aplicaría a los esclavos.

46 Respecto a la formación de la Comisión hubo diversos intentos por parte de los sectores más acomodados de la sociedad cubana, de que la misma no se celebrara, valga destacar al respecto, el telegrama que Julián de Zulueta y el conde de Cañongo, en nombre de un grupo de * notables" cubanos dirige al Ministro Becerra, en el que solicita se suspendan las reformas sociales y políticas hasta que la tranquilidad de la isla permita a ésta tener representación en Cortes, haciéndose la reorganización fundamental de las dos islas a la vez, porque las reformas sociales y políticas que se pedían para Puerto Rico habían de influir en Cuba y " habian de ocasionar grandes conflictos en la posesión española de mayor población y riqueza"; destáquese, igualmente, a modo de ejemplo, el escrito dirigido por el Presidente del Casino al General Prim, en la que le encarecía "la necesidad imprescindible de que nada se resuelva prematuramente" y recordándolo que no se podía gobernar aquella isla con arreglo a los mismos principios que se empleaban en la península. Sin embargo, los requerimientos cubanos, sólo sirvieron para que no fuera tratado el tema cubano centrándose por tanto, las actividades de la comisión en la isla de Puerto Rico. En ROLDÁN MONTAUD I., La Unión Constitucional y la política colonial de España en Cuba (1868-1898), pág. 70. Universidad Complutense. Madrid.1991.

47 No obstante, se limitaban la libertad de imprenta y de enseñanza.

48 El Gobernador contaba con la posibilidad de suspender las garantías individuales reconocidas en la Constitución.

49 De esta forma, se derogaban las Leyes de Indias que estuvieran vigentes.

50 Sobre el Proyecto de Becerra, véase DE LABRA R.M., La cuestión de Puerto Rico. Imprenta de J.F. Morete, Madrid.1870.; véase igualmente sobre la relación entre España y las posesiones españolas en Las Antillas, DOMINGO ACEBRÓN M.D., Rafael María de Labra. Cuba, Puerto Rico, Las Filipinas, Europa y Marruecos, en la España del Sexenio Democrático y la Restauración (1871-1918), CSIC, Madrid.2006. 
Moret, cuando ocupara el Ministerio de Ultramar, la lentitud de las Cortes españolas y los acontecimientos políticos acaecidos en España pondrían fin al Proyecto y la Monarquía de Amadeo de Saboya, dando paso a la Primera República española.

El Proyecto constitucional de 1873, que estableció un régimen de carácter liberal-radical y federalista, ${ }^{51}$ será el primer texto de la historia constitucional española, con la excepción del gaditano, que prescinda de las denominadas "Leyes Especiales" ${ }^{52}$ para el gobierno de las posesiones americanas; sin embargo, este texto no pasó de ser un Proyecto, en cuanto que nunca tuvo vigencia debido a la situación de guerra civil que vivía España y al golpe de Estado militar que derribó el régimen republicano. ${ }^{53}$

En su artículo $1^{\circ}$ proclama que Cuba y Puerto Rico son Estados ${ }^{54}$ de la Nación española, ${ }^{55}$ gozando de completa autonomía .económico-administrativa y toda la autonomía política compatible con la existencia de la Nación (art. 92), contando con una Constitución de Estado, compatible con la de la Federación, (art. 93“).

Los Estados contaban con amplias atribuciones, ${ }^{56}$ así como los municipios, sujetos igualmente al principio descentralizador. ${ }^{57}$ Aunque contaban como los diferentes Estados con un delegado del Poder Ejecutivo de la Federación, éste, sólo se limitaba a vigilar el cumplimiento de la Constitución y de las leyes, de los decretos y de los reglamentos federales, pero sin autoridad ninguna especial dentro del Estado. ${ }^{58}$

51 Véase al respecto del pensamiento republicano referente al tema colonial. LÓPEZ CORDÓN M.V. El pensamiento político internacional del federalismo español, Planeta, Barcelona, 1975.

52 No obstante, en el texto se mantendrán las Leyes Especiales, en su artículo 44, para el gobierno de las restantes posesiones españolas, aunque la formulación de las mismas difiere ampliamente de lo proclamado en otros textos anteriores, ya que les otorga un sentido de provisionalidad "territorios en que no se han desarrollado todavia suficientemente los organismos políticos...", así como un carácter marcadamente progresista "...destinadas a implantar alli los derechos naturales del hombre y a procurar una educación humana y progresiva".

53 Por otra parte, debe destacarse la decidida oposición de los sectores económicos dominantes en Cuba ante el advenimiento del régimen republicano, de tal forma, que consiguieron paralizar las operaciones mercantiles, divulgando todo tipo de falsas informaciones, tales como que España pensaba abandonar la isla, entregándosela a los insurrectos etc. En el fondo subsistía el miedo a que se pusiera fin al esclavismo, en virtud del recuerdo del discurso que pronunciara el Presidente Cautelar en las Cortes el 21 de diciembre de 1878, en el que de alguna forma, había proclamado los principios republicanos referentes a los territorios ultramarinos "Que España sea acción y no reacción; libertad y no arbitrariedad; justicia y no privilegio; abolición de la esclavitud, y no eterno predominio del negrero en la parte más hermosa del planeta".

54 Los restantes Estados son: Andalucía Alta, Andalucía Baja, Aragón, Asturias, Baleares, Canarias, Castilla la Nueva, Castilla la Vieja, Cataluña, Extremadura, Galicia, Murcia, Navarra, Valencia y las Regiones Vascongadas.

55 El texto constitucional no proclama como Estados a las restantes posesiones españolas en Asía y África, aunque no cierra sus puertas a ello, en virtud de "sus progresos" (art. $2^{\circ}$.)

56 Las atribuciones de los Estados se proclamaban en el Título XIII (arts 92 a 105). Las Facultades correspondientes a los Poderes Públicos de la Federación se hacía en el Título V .

57 Las atribuciones de los Municipios se proclamaban en el Título XIV (arts 106 a 109).

58 Art. 72.8 . 
La representación que correspondía a las islas antillanas en las Cortes de la Nación, estaba sujeta a los mismos principios de los restantes territorios de la Federación, siendo para el Senado, que era la Cámara territorial, de cuatro representantes por Estado, ${ }^{59}$ independientemente de la importancia y número de habitantes del Estado: El Congreso de los Diputados, que representaba a la población, y cuyos miembros eran elegidos por sufragio universal masculino directo, estaba compuesta por diputados electos cada 50.000 habitantes. ${ }^{60}$

El Título XIII de la Constitución de 1876, que consta de un único artículo, proclama, igual que en textos anteriores, con la salvedad del proyecto constitucional republicano indicado en el párrafo anterior, que las provincias de ultramar serán gobernadas por leyes especiales, sin embargo, a diferencia de los anteriores textos constitucionales, se proclama el deseo por parte de los constituyentes, de que las leyes promulgadas para la península o que se puedan promulgar tengan vigencia en los territorios de ultramar, ${ }^{61}$ con las modificaciones que considere el Gobierno, ${ }^{62}$ que a este efecto queda autorizado por el artículo 89 de la Constitución.

Por otra parte, cabe destacar, que a pesar de que el texto preveía que pudieran aplicarse en las islas caribeñas la legislación española, este aspecto no pudo ser posible, en virtud del permanente estado de agitación política existente en las mismas, especialmente en la isla de Cuba, así como por los omnímodos poderes con que contaba el Gobernador ${ }^{63}$ de las respectivas islas, que le permitían intervenir en el gobierno de ayuntamientos y Diputación, cuando a su juicio estas instituciones se extralimitaran en sus funciones, lo que de hecho significaba la existencia de un estado permanente de excepción.

Sin embargo, no será hasta abril de 1881, que mediante Real Decreto ${ }^{64}$ se extenderá la Constitución a Puerto Rico y Cuba; ${ }^{65}$ así mismo, durante este pe-

59 Art. 52

60 Art 51.

61 El antecedente de la aplicación de las leyes españolas podemos encontrarlo en el artículo 108 de la Constitución de 1869, aunque en este caso, sólo se refería a los derechos proclamados, mientras que en el texto de 1876, el sentido es más amplio indicando "las leyes promulgadas o que se promulguen para la Península" (art. 89).

62 En este punto, se percibe una gran diferencia con el ya citado texto de 1869, pues mientras en aquél correspondía a las Cortes, en el texto de la Restauración tal protagonismo lo detenta el Gobierno.

63 Los poderes del Gobernador se vieron fuertemente reforzados, en virtud del Real Decreto de 9 de junio de 1878 .

64 Sin embargo la vigencia constitucional no se produciría hasta la publicación del texto en las respectivas Gacetas Oficiales, lo que ocurriría en el mes de junio.

65 Previamente y aunque ello no implicaba la extensión de la Constitución de 1876 a la isla, mediante el pacto de Zanjón de 10 de febrero de 1878, se proclamaba en el artículo $1^{\circ}$, que se concedería a Cuba "las mismas condiciones políticas, orgánicas y administrativas de que disfruta la isla de Puerto Rico". No obstante, para la isla de Cuba la aplicación del texto de 1876 irá mucho más lenta que en el caso de Puerto Rico, como consecuencia de la guerra habida hasta la paz de Zanjón de 1878, así hasta un R.D. de 20 de marzo de 1882 no se autorizó al Ministro de Ultramar para presentar a las Cortes el proyecto de ley del Gobierno General de la isla de Cuba. 
riodo se promulgarán para las islas antillanas una serie de normas tendentes a la consolidación del Estado de Derecho, así se promulgará la libertad de imprenta, adaptando la española de 7 de enero de 1879, que comenzará a regir en Puerto Rico en $1980^{66}$ y en Cuba en $1880,{ }^{67}$ que culminará en la proclamación de un texto específico para ambas islas en 1886; ${ }^{68}$ la libertad de reunión se proclamará para Puerto Rico, ${ }^{69}$ y Cuba $1881,{ }^{70}$ la ley de enjuiciamiento civil, ${ }^{71}$ la ley de enjuiciamiento criminal, que fue declarada vigente en las islas en $1888,{ }^{72}$ así como el Código Civil, ${ }^{73}$ que fue aplicado sin restricción alguna, y que posiblemente supone el intento más importante de llegar a la unidad de legislación.

Este proceso de aplicación del texto constitucional español en las islas caribeñas ${ }^{74} \mathrm{y}$ de reforma de la administración de las mismas culminará en la ley de Bases de $1895,{ }^{75}$ siendo Ministro de Ultramar D. Buenaventura de Abárzuza. ${ }^{76}$

\section{LA LEY DE BASES DE 1895}

La ley de Bases nunca tuvo vigencia en Cuba, como consecuencia de que el 14 de febrero de 1895, se producía el denominado "grito de Baire" comenzando de nuevo un levantamiento militar independentista en dicha

66 R.D. de 27 de agosto de 1880.

67 R.D. de 7 de abril de 1881.

68 R.D. de 11 de noviembre de 1886.

69 R.D. de 1 de noviembre de 1881.

70 De esta forma, se extendía a los territorios americanos la ley de 15 de junio de 1880, vigente en España, que desarrollaba lo dispuesto en el artículo 13 de la Constitución.

71 R.O. de 28 de septiembre de 1885.

72 R.D. de 19 de octubre de 1888, modificado por otro R.D. de 7 de diciembre del mismo año.

73 R.D. de 31 de julio de 1889.

74 La plena vigencia de la Constitución de 1876, incluido el Título I, referente a los derechos y libertades, no se aplicará a las islas caribeñas hasta el R.D. de 25 de noviembre de 1897.

75 Ley estableciendo las bases para el régimen del Gobierno y la Administración civil de las Islas de Cuba y Puerto Rico, de 15 de marzo de 1895.

76 La ley tiene en su base un proyecto de 1893 de Maura, cuando éste ocupara la cartera de Ultramar .El Proyecto Maura proponía la creación de una Diputación Provincial con amplios poderes sobre obras públicas, sectores productivos, comunicaciones, educación etc, así mismo, otorgaba a dicho órgano la capacidad para elaborar y aprobar los presupuestos de las respectivas islas y poder proponer al Gobierno español, por medio del Gobernador enmiendas a la legislación aplicable a las islas. Se completaba la organización político-administrativa de los territorios americanos mediante la conformación de un Consejo de Administración, cuyas atribuciones eran de carácter consultivo; el Gobernador, aunque con funciones recortadas, en virtud de las atribuciones asumidas por la Diputación, seguía gozando de amplios poderes, en cuanto estaba a la cabeza del gobierno civil y ostentaba el mando de las fuerzas armadas. El Proyecto de Maura incluía la existencia de ayuntamientos electos, que permitían la representación de las minorías y contaban con gran autonomía. No obstante, el Proyecto no reconocía el sufragio universal masculino ya existente en la metrópoli, siendo censitario. 
isla. ${ }^{77}$ Es por ello, que nos referiremos exclusivamente a dicha ley en relación con la Isla de Puerto Rico.

Esta norma conformaba los siguientes órganos de gobierno:

La Diputación Provincial. Compuesta por doce miembros, que desempeñarían el cargo durante cuatro años, renovándose por la mitad de dos en dos, de los que correspondían seis a cada una de las Regiones ( Ponce y San Juan) en que se dividió la isla, que recibía el nombre de provincia. El órgano contaba con un Presidente elegido por sus miembros. ${ }^{78}$ Los miembros de la Diputación eran responsables individualmente de las decisiones que adoptaran. ${ }^{79}$

Entre sus atribuciones correspondía a la Diputación Provincial, lo concerniente a obras públicas, comunicaciones telegráficas y postales, terrestres y marítimas, agricultura, industria y comercio, inmigración y colonización, instrucción pública, beneficencia y sanidad. ${ }^{80}$

Respecto a los Presupuestos, aunque sus atribuciones, eran algo más restrictivas que en el anterior proyecto de Maura, le correspondía su elaboración y aprobación anual. Podía revisar igualmente los acuerdos de las Corporaciones municipales relativos a formación o alteración de sus presupuestos, sin mermar las facultades discrecionales de aquellas, cuidando de que no se autorizara gasto alguno que excediera de los recursos efectivos, y de que, con preferencia a toda otra necesidad, se solventaran los débitos o atrasos que resultaran de un año para otro y las obligaciones que hubieren sido declaradas por ejecutoria de los Tribunales competentes. Aprobaba o desaprobaba en definitiva las cuentas anuales de los Municipios, declarando, en su caso, sin ulterior recurso, las responsabilidades administrativas a reserva de las que eran competencia de los Tribunales ordinarios. ${ }^{81}$

No obstante, las atribuciones de la Diputación Provincial quedaban claramente mermadas, en virtud de que en la propia ley de Bases, a continua-

77 La imposibilidad de aplicar la citada ley en Cuba, en virtud de la guerra, no significó que el gobierno español renunciase a la concesión de autonomía para la isla, como puso de manifiesto el Presidente del Consejo de Ministros, Cánovas del Castillo, en respuesta a la nota amenazadora norteamericana del Secretario de Estado Richard Onley de 4 de abril, en la que el 22 de mayo del mismo año manifestó que pensaba "dotar a entrambas Antillas de una personalidad administrativa y económica de carácter exclusivamente local, pero que haga expedita la intervención total del país en sus negocios peculiares, bien que manteniendo intactos los derechos de la soberanía, Y, como indica, Fraga Iribarne, a la vez que justificaba con la guerra presente la no aplicación de la ley Abárzuza, se daba a entender que sería otra más avanzada la que se aplicaría después de lograda la pacificación. En FRAGA IRIBARNE, M.: Las constituciones de Puerto Rico ob, ant, cit., pag. 26; Véase igualmente, PORTELL VILÁ, H., Historia de Cuba en sus relaciones con Estados Unidos y España .T.III pág. 188..J. Montero. La Habana 1939.

78 Ley de Bases. art. $2^{\mathrm{a}}$. Base $2^{\mathrm{a}}$.

79 «Si algún acuerdo de la Diputación Provincial lesionaba derechos de particulares, los que hubiesen contribuido con su voto a adoptarlo serán responsables de indemnización o restitución al perjudicado ante los Tribunales competentes" (Ley de Bases. art. $2^{\mathrm{a}}$.Base $2^{\mathrm{a}}$.).

80 Dichas atribuciones se ejercían por la Diputación Provincial "con arreglo a las leyes y reglamentos", "sin perjuicio de la alta inspección y de las facultades inherentes a la soberanía que las leyes reserven al Gobierno de la Nación" (Ley de Bases. art. $2^{\mathrm{a}}$. Base $2^{\mathrm{a}}$.).

81 Ley de Bases. art. $2^{\text {a }}$. Base $1^{\text {a }}$. 
ción de las facultades de la misma, manifestaba, que se ejercerían, "sin perjuicio de la alta inspección y de las facultades inherentes a la soberanía que las leyes reserven al Gobierno de la Nación"; 82 así mismo, podía ser suspendida en sus funciones, cuando el Gobernador General, oída la Junta de Autoridades, o sin el cumplimiento de dicho requisito, considerase que, se habían producido los siguientes supuestos: $1^{\circ}$ "Cuando la Diputación o alguno de sus miembros traspase el límite de sus facultades legitimas, con menoscabo de la Autoridad gubernativa o judicial o con riesgo de la alteración del orden público". $2^{\circ}$. "Por razones de delincuencia". En el primer caso, el Gobernador debía dar cuenta inmediatamente al Gobierno de la Nación, con el fin de que éste levantara la suspensión o decretara la destitución por acuerdo adoptado en Consejo de Ministros, dentro del plazo de dos meses, contados desde la fecha en que saliera el primer correo directo para la Península, transcurridos los cuales sin una u otra providencia, quedaría alzada de derecho la suspensión; en el segundo caso, el asunto quedaría sujeto a la resolución de los Tribunales competentes. ${ }^{83}$

El Consejo de Administración. Presidido por el gobernador general, contaba con los siguientes miembros natos: El Rvdo. Obispo de Puerto Rico, el General Segundo Cabo, el Comandante Principal de Marina, el Presidente y el Fiscal de la Audiencia Territorial y el Teniente Coronel del Cuerpo de Voluntarios de la capital, a los que se sumaban los Diputados Provinciales de la región en que esté más próxima la elección ordinaria para la renovación bienal. A su vez el Gobierno nombraba por Real Decreto otros seis Consejeros, dos de los cuales tenían las calidades legales, la categoría y el sueldo de Jefes de Administración de primera clase, ${ }^{84}$ y estaban encargados de las ponencias ${ }^{85}$ que eran necesarias para preparar las deliberaciones del Consejo. ${ }^{86}$

El Consejo era un órgano consultivo, que deliberaba siempre en pleno, aunque podía constituir Comisiones, que informaban al Pleno ${ }^{87}$.

82 Ley de Bases. art. $2^{\mathrm{a}}$. Base $2^{\mathrm{a}}$.

83 Sin embargo, la intervención del Gobernador General, no es mayor que la prevista en el texto constitucional de 1876, respecto a las restantes Diputaciones provinciales peninsulares, así el artículo $84.4^{\circ}$, proclama que se producirá la "Intervención del Rey, y en su caso de las Cortes, para impedir que las Diputaciones provinciales y los Ayuntamientos se extralimiten de sus atribuciones en perjuicio de los intereses generales y permanentes".

84 Los restantes vocales del Consejo lo hacían de forma honorífica y gratuita.

85 Para desempeñar el cargo de ponente en el Consejo, era requisito imprescindible haber servido un año en la isla como Jefe de Administración.

86 Así mismo, el Consejo, por conducto del Gobernador General, podía llamar a su seno, para oírlos, pero sin derecho a voto, a los Jefes de los servicios administrativos.

87 El Consejo debía ser oído en los siguientes casos:

1. Sobre los presupuestos generales de gastos e ingresos, cuyos proyectos, que habrá formado la Intendencia, serán elevados todos los años dentro del mes de marzo, o antes, al Ministerio de Ultramar, con las modificaciones hechas por el Consejo. Aunque el Gobierno varíe el proyecto para presentarlo a las Cortes, a fin de proveer los servicios y obligaciones generales del Estado, acompañará siempre como informe el redactado por el Consejo.

2. Sobre las cuentas generales que la Intendencia de Hacienda rendirá sin excusa todos los años, dentro del semestre siguiente a cada ejercicio económico, comprensivas de los ingresos y 
El Gobernador General. Era el representante del Gobierno de la Nación en la isla de Puerto Rico, como Visceral Patrono, ejercía las facultades inherentes al Patronato de Indias. Ostentaba el mando superior de las fuerzas armadas de mar y tierra existentes en la isla. Era el delegado de los Ministerios de Ultramar, de Estado, de Guerra y de Marina, y le eran subordinadas todas las demás autoridades de la Isla. Su nombramiento o separación del cargo emanaba de la Presidencia del Consejo de Ministros, con acuerdo de éste, a propuesta del Ministro de Ultramar. ${ }^{88}$

Además de las otras funciones que por precepto de las leyes, o por especial delegación del Gobierno le correspondían, contaba con las siguientes atribuciones: a) Publicar, cumplir y hacer que se cumplan los decretos, Reales órdenes y demás disposiciones emanadas del Poder Ejecutivo y que le comuniquen los Ministerios de que es delegado ${ }^{89}$; b) Vigilar e inspeccionar los servicios públicos; c) Comunicarse directamente, sobre negocios de política exterior, con los representantes, agentes diplomáticos y cónsules de España en América; d) Suspender las ejecuciones de pena capital cuando la gravedad de las circunstancias y la urgencia no diere lugar a solicitar y obtener de S.M. el indulto, ${ }^{90}$ oyendo el parecer de la Junta de Autoridades; e) Suspender bajo su responsabilidad y audiencia de la Junta de Autoridades, en caso de que circunstancias extraordinarias impidieran comunicarse previamente con el Gobierno, determinados derechos fundamentales recogidos en el texto constitucional (habeas corpus, inviolabilidad de domicilio, libre residencia, libertad de expresión, reunión y asociación ${ }^{91}$ ).

Como Jefe superior de la Administración civil en la isla, también correspondía al Gobernador General: a) Mantener la integridad de la jurisdicción administrativa con arreglo a las disposiciones que rigen en materia de competencia de jurisdicción y atribuciones; b) Dictar las disposiciones generales necesarias para el cumplimiento de las leyes y reglamentos, dando cuenta de ellas al Ministerio de Ultramar ${ }^{22}$; c) Señalar los establecimientos penales en

gastos liquidados y realizados en la administración del presupuesto general de la isla. 3. Sobre los asuntos del Patronato de Indias. 4. Sobre los acuerdos de la Diputación Provincial que den ocasión a que intervenga el Gobierno, con arreglo a la base $2^{\mathrm{a}}$. 5. Sobre las peticiones de reformas legislativas que emanen de la Diputación antes de elevarlas al Gobierno. 6. Sobre la destitución o separación de Alcaldes o Regidores. 7. Sobre los demás asuntos de carácter administrativo que las leyes determinen. Podrá, además, el Gobernador General pedir al Consejo cuantos informes considere convenientes.."

88 Ley de Bases. art. $2^{\mathrm{a}}$. Base $4^{\mathrm{a}}$.

89 Cuando a juicio del Gobernador las resoluciones del Gobierno pudieran causar daños a los intereses generales de la Nación o a los especiales de la Isla, podía suspender su publicación y cumplimiento, dando cuenta de ello y de las causas que motiven la resolución, por el medio más rápido, al Ministerio respectivo. ( Ley de Bases. art. $2^{\mathrm{a}}$. Base $4^{\mathrm{a}}$.).

90 La Constitución de 1876, ‘proclamaba en el artículo 54.3, que correspondía al Rey “Indultar a los delincuentes con arreglo a las leyes".

91 Arts 1, 5,6,9 y13.

92 Cuando el Gobierno haya dictado reglamentos u órdenes para el debido cumplimiento de las leyes, el Gobernador General se ajustará estrictamente a lo dispuesto por aquél. (Ley de Bases. art. $2^{\mathrm{a}}$. Base $4^{\mathrm{a}}$.). 
que se deban cumplir las condenas, disponer el ingreso en ellos de los penados y designar el punto de confinamiento cuando los Tribunales impongan esta pena; d) Suspender a los funcionarios de la Administración cuyo nombramiento corresponda al Gobierno, dando a éste cuenta razonada, y proveer interinamente las vacantes, con arreglo a las disposiciones vigentes; e) Sostener con los Ministros de que es delegado la comunicación de todas las Autoridades de la Isla.

No obstante, el verdadero carácter del Gobernador general, que lo diferencia de sus homólogos peninsulares y que todavía pone de manifiesto el carácter colonial de la Isla, estriba en que en caso de quedar vacante el puesto por ausencia o imposibilidad su sustitución se lleva a cabo por el General Segundo Cabo, y en defecto de éste por el Comandante General del Apostadero, mientras el Gobierno no designase otra persona para la interinidad dicha.

El Gobernador General contaba igualmente con importantes atribuciones respecto al Poder Municipal, así, aunque los Alcaldes eran electos entre los concejales del respectivo municipio, si el Gobernador General lo estimaba oportuno podía nombrar como Alcalde a otro miembro de la Corporación; ${ }^{93}$ así mismo, podía suspender acuerdos municipales. ${ }^{94}$

La Junta de Autoridades.

Se trata de un órgano consultivo, ${ }^{95}$ presidida por el Gobernador General ${ }^{96}$ y compuesto por el Rvdo. Obispo de San Juan de Puerto Rico, el General Segundo Cabo, el Comandante principal de la Marina, el Presidente y el Fiscal de la Audiencia de San Juan, el Intendente de Hacienda y el Jefe de la Sección de Administración Local.

Aunque los acuerdos de la Junta estaban supeditados a la voluntad del Gobernador General, «que resolverá bajo su autoridad lo que crea más conveniente, ${ }^{97}$ sin embargo, los mismos se hacían constar en acta duplicada, remitiendo un ejemplar al Ministerio de Ultramar. ${ }^{98}$

La Ley de bases fue desarrollada y complementada mediante la promulgación de una serie de decretos, de fecha 31 de diciembre de $1896^{99}$, siendo

93 Para la destitución gubernativa de Alcaldes y Concejales, el Gobernador General debía oír previa y necesariamente al Consejo de Administración.

94 En caso de suspensión gubernativa de acuerdos municipales, si la misma se debía por razón de delincuencia, debía pasar la misma a conocimiento del Tribunal ordinario, o a conocimiento de la Diputación Provincial, para que ésta confirmara o revocara la suspensión, en el caso de que la misma se debiere a acuerdos municipales ajenos a las competencias locales.

95 Era de obligada consulta cuando se suspendía en sus funciones la Diputación Provincial, así como cuando se procediera a otorgar indulto por el Gobernador General o cuando se suspendieran los derechos y libertades proclamados en el texto constitucional.

96 En la ley de Bases de 1885 no se indica que la presidencia corresponda al Gobernador general, aunque sí la subordinación de este organismo ante el mismo, sin embargo, en el R.D. de 31 de diciembre de 1896 "Sobre las atribuciones del Gobernador General de la Isla de Puerto Rico", se proclama en su artículo 16, que la presidencia corresponde al Gobernador.

97 Ley de Bases. art. $2^{a}$. Base $4^{\text {a }}$. y art. 18, R.D. de 31 de octubre de 1806.

98 Ley de Bases. art. $2^{\text {a }}$. Base $4^{\mathrm{a}}$. y art. 17, R.D. de 31 de octubre de 1806.

99 Fueron publicados el $1^{\circ}$ de enero de 1897. 
presidente del Consejo de Ministros Cánovas del Castillo y Ministro de Ultramar Castellano y Villarroya; los Decretos afectaban la totalidad de los órganos de gobierno previstos en la ley de Bases de 1895, así se producirá uno sobre "Atribuciones del Gobernador General de la Isla de Puerto Rico", que afectaba no sólo a la figura del Gobernador, sino también a la Junta de Autoridades, otro sobre la "Organización y funciones del Consejo de Administración de Puerto Rico", otro sobre la "Organización de la Administración civil y económica de Puerto Rico", completándose con un cuarto "Inspección y Recurso de Queja", que regulaba el recurso de queja y el recurso contencioso-administrativo en la Isla, así como otro que aprobaba la ley municipal, y varios más referentes a la organización territorial de la isla y la ley electoral para la elección de Concejales y Diputados.

Sin embargo, así como la Ley de Bases de 1895 tuvo una favorable acogida en los sectores autonomistas de Puerto Rico, pues se pensaba que abría un camino para el autogobierno de la isla e incluso sería un referente para la vecina Cuba, inmersa en aquél momento en un conflicto armado, los decretos del Gobierno Cánovas provocaron desilusión y rechazo en la clase política puertorriqueña, pues como indica Trías Monge, ${ }^{100}$ "Estos decretos no hacían otra cosa que desenvolver las bases establecidas por la fórmula Abárzuza, sin añadir, contrario a la expectación general causada por promesas anteriores de Cánovas, detalle fundamental alguno que significase la ampliación de las mismas".

A este respecto, cabe destacar la respuesta de rechazo dada por el Partido Autonomista de Puerto Rico, mediante el manifiesto de 2 de febrero de 1897, ${ }^{101}$ "Amargo descontento han producido en el país los decretos del Gobierno de don Antonio Cánovas del Castillo, desenvolviendo las Bases de la Ley de quince de marzo del año noventa y cinco para la reorganización de Cuba y Puerto Rico (...) Los Decretos ...restringen aún más el espiritu restrictivo de las Bases, y con declaraciones pomposas traerán efectivamente un desengaño pernicioso al pais, que no puede aceptar las pretendidas reformas sin riesgo de hacerse cómplice del engaño con que el Gobierno las anunció. Grave irresponsabilidad es la de defraudar las legitimas esperanzas de un pueblo después de tanto como se ha encarecido la necesidad de cambiar radicalmente el régimen politico y administrativo de las Antillas (...).

Sin embargo, la actitud del gobierno español respecto a las posesiones antillanas, en muy poco tiempo, tomará un rumbo diferente, de tal forma, que optará claramente por la vía autonómica; siendo varias las razones que influirán en esta decisión, destacando especialmente la situación de la guerra de Cuba, imposible de resolverse militarmente, y sobre todo la actitud intervencionista de los Estados Unidos de Norteamérica. A este respecto, resulta es-

100 TRÍAS MONGE, J., ob, ant, cit., pág. 97.

101 El manifiesto se reproduce completo en el apéndice XVI de CRUZ MONCLAVA, op. cit., T.III, $2^{a}$ parte págs. 456-461. Un extracto del mismo, comentado en Trías Monge, ob, ant, cit pág. 97 y ss. 
pecialmente clarificadora la exposición de motivos que hace el Presidente del Consejo de Ministros. D. Antonio Cánovas del Castillo para "Ampliación de las reformas acordadas en 1895 para Puerto Rico. ${ }^{102}$

La exposición de motivos supone en primer lugar un reconocimiento del problema real de los territorios antillanos y un análisis crítico de la actitud histórica española al respecto, así, manifiesta Cánovas respecto a la justificación de la guerra, y a la imposibilidad de aplicar las reformas prevista en 1895, "Importa Señora, ante todo recordar los antecedentes. Cada dia aparece más claro que la larga conjura que precedió a la guerra no se fraguó con el fin obtener concesiones compatibles con la soberania española, sobrando auténticos documentos donde se patentizara que nunca pensaron sus autores sino en la independencia de la Isla ( se refiere a Cuba), Llegó a punto este empeño, cual nadie ignora, que la ley de reformas de 15 de marzo de 1895, con tan buena fe votada por las Cortes por los partidos peninsulares y cubanos, lejos de contener, precipitó la sublevación, para impedir que ni poco ni mucho influyesen sus beneficios en el sostén de la paz. Por tan forzoso motivo, la Nación española, que desde mucho antes tenía a sus Antillas otorgados cuantos derechos políticos acepta unánimemente la civilización moderna, y que, al mismo tiempo en que se empezó a hostigar su soberanía, estaba procurando establecer sus reformas administrativas, sin disputas liberales $y$ descentralizadoras, twvo que acudir con las armas a la defensa de su integridad territorial. No faltaron espiritus a quienes persuadiese su propia generosidad, en los primeros días, de que la mera aplicación de las reformas desvanecería los proyectos de los conjurados; mas en la generalidad de los españoles bien pronto se impuso el convencimiento de que se trataba de otra guerra separatista, cuya ineficacias habia que demostrar antes que las concesiones produjeran efectos útiles".

En la misma exposición de motivos, el Presidente Cánovas, pone de manifiesto, consecuencia del desarrollo de la guerra y de la posible intervención americana en el conjunto, su deseo de que el proceso descentralizador siga avanzando, "(...) Por descontado que la ley que tenian las Cortes hasta entonces votadas, nunca se debió entender como final término de una evolución, tan madura y sinceramente iniciada por la Metrópoli. Muy bien pudo dudarse en anteriores tiempos que a los propios españoles de las Antillas conviniera entrar de repente en una administración autónoma, dados los perniciosos efectos que en materias tales ocasiona la precipitación. Sin salir de Cuba, habiase ya esto experimentado con la súbita e ilimitada libertad de imprenta, que tamaña parte tuvo en la preparación de la guerra. Mas así y todo, ¿qué hombre de Estado español ni extranjero debió imaginar que allí donde tan latos derechos políticos existían hubiera de registrarse una legislación administrativa en consonancia con la politica perpetuamente? De buena fe no cabia, no, pen-

102 R.D. de 4 de febrero de 1897, publicado el día 6 del mismo mes. Mediante el mismo pasaba a informe del Consejo de Estado el citado Proyecto, lo que suponía una cierta infracción constitucional, que el propio Cánovas justifica por la urgencia del caso. 
sar que las disposiciones de la ley de 15 de marzo de 1895 tuviesen carácter definitivo."

Sobre los límites de la descentralización, se manifiesta igualmente el Presidente del Consejo de Ministros, así, invocando el discurso de la Reina Regente al inicio de la legislatura de las Cortes, "V.M. ofreció dotar a entrambas Antillas, tan pronto como el estado de guerra lo consintiera, de una personalidad administrativa y económica de carácter exclusivamente local, pero que hiciera expedita la intervención total del país en sus negocios peculiares, bien que manteniendo intactos los derechos de la soberania e intactas las condiciones indispensables para sus subsistencias. Desde entonces fue certísimo que a semejante fin encaminaría cualquier gobierno español todos sus pasos. (...) para atender a la real necesidad que la isla siente de experimentar lo que los ingleses titulan self government, o sea, una descentralización amplia, capaz de permitir al país la administración de sus peculiares intereses y de hacer que él tome sobre sí, a la par, las responsabilidades que por sus actos le toquen, descargando de ellas a la Península.

Respecto a la intervención extranjera, Cánovas, alejado de una política de confrontación, intenta convencer a Estados Unidos de la seriedad de la propuesta española, “(...) la preocupación general en América y en Europa de que obstinadamente negábamos los peninsulares a nuestros hermanos de Cuba y Puerto Rico lo que en otras ocasiones otorgaban a sus provincias ultramarinas, preocupación que nos estaba en grado no corto perjudicando. Tal idea era y es verdaderamente injusta, según lo prueban nuestra tradición y nuestra misma conducta muchos años ha en el orden político de las Antillas; mas no por eso debia el gobierno despreciarla, sino antes bien acudir a desvanecer las causas del común sentir con patentes hechos. En ningún tiempo, a decir verdad, ha sido útil para nación alguna el separarse en sus procedimientos políticos de la corriente general de las demás, y la historia de España con exceso lo demuestra; pero mucho menos hoy. Cuando la solidaridad de los pueblos civilizados llega a tanto, que el mero desacuerdo en las formas con el sistema general de las naciones predominantes suele traer inconvenientes. Claro está que la dignidad nacional rechazará siempre, y en todas partes, todo cuanto no sea expresión de la propia conciencia, intima y espontáneamente formada, y mucho más cualquier linaje de imposición forastera; mas no quiere esto decir que Poder alguno deba por sistema sustraerse a la opinión pública, que cuando está legítimamente expresada y llega como a causar estado, merece igual respeto que de los individuos, de las grandes asociaciones humanas."

El Real Decreto para el Proyecto de ampliación de reformas, fue aprobado el 4 de febrero, mediante trámite de urgencia, pasando al Consejo de Estado para informe, en virtud de que el mismo no había sido aprobado por las Cortes, lo que representaba una dudosa constitucionalidad del mismo, como el propio Cánovas manifestara "Mas hora es ya de reconocer, Señora, que resoluciones de parecido alcance no son de las que constitucionalmente corresponden siempre en los países libres al Poder Ejecutivo. Tan sólo el carácter notoriamente extraordinario de las circunstancias presentes ha podido per- 
suadir al Gobierno de V.M. de que debía adoptarlas bajo la forma de un Decreto con audiencia del Consejo de Estado, y del cual se dé cuenta a las Cortes, a fin de que obtengan de las mismas la rigurosa legitimidad que les falter. Las razones de la urgencia las explica el propio Cánovas, "someter puntos tales a una discusión detallada y larga, estando viva la guerra, hubiera traído inconvenientes que, por notorios, no bay para qué exponer en este momento. Nuestra Constitución misma reconoce en caso de guerra extranjera a la Corona, asi como el derecho de declararla, el de hacer y ratificar la paz, dando después cuenta documentada a las Cortes. Y si la de Cuba no es extranjera, en verdad, bien se ve que, por la enorme cuantía de los sacrificios en hombres y dinero que a la Nación impone, muy bien puede compararse con las de aquella indole que hemos sostenido en otras épocas. ${ }^{103}$

El Real Decreto de urgencias para el Proyecto de Ampliación de reformas de 4 de febrero de 1897, así como el Real Decreto de 23 de abril del mismo año, mandando se constituyan la Diputación Provincial y el Consejo de Administración, el Real Decreto de 29 de abril, que daba cumplimiento a la Ampliación de las Bases, representan el intento máximo del gobierno Cánovas por dotar de un cierto grado de autonomía a los territorios caribeños; no obstante, cabe destacar que las reformas de los gobiernos Cánovas, no tenían fuerza dispositiva propia, sino que eran "Bases", necesitaban ser desarrolladas por Decretos y Reglamentos posteriores, lo que añadía un considerable retraso a su vigencia en los territorios antillanos, especialmente en la Isla de Cuba en la que la aplicación "quedaba supeditada siempre a que lo permitiera el estado de guerra". Por otra parte, cabe destacar que las reformas de Cánovas no llegaron a introducir el sufragio universal masculino existente en el territorio metropolitano; ${ }^{104}$ tampoco llegaron a aplicarse la totalidad de los derechos y libertades individuales proclamados en la Constitución de 1876, en virtud de que precisaban de los correspondientes Decretos, no dando respuesta tampoco a la petición autonomista antillana de la existencia de parlamentos isleños y de recortar las atribuciones de los Gobernadores Generales.

\section{LAS CARTAS AUTONÓMICAS}

Con la muerte de Cánovas en agosto de 1898 y la subida al poder del partido liberal, figurando a la cabeza del Consejo de Ministros Don Práxedes Mateo Sagasta, ${ }^{105}$ el proceso autonómico de las islas antillanas, como conse-

103 Cánovas. Exposición de motivos. R.D. 4 de febrero de 1897.

104 La legislación electoral española de 26 de julio de 1896, no se aplicaría hasta la proclamación de las Cartas Autonómicas.

105 La política del partido liberal respecto al "status" de los territorios antillanos en el ordenamiento constitucional español difería en gran medida del defendido por el partido conservador, especialmente en los últimos años, valga recordar al respecto, el discurso de Segismundo Moret, que posteriormente sería el artífice de los Estatutos, en agosto de 1897, en la ciudad de Zaragoza, en el que manifestó "No se trata de la autonomía del Canadá, ni de Australia, ni de la Colo- 
cuencia de la situación de guerra en Cuba y de las presiones norteamericanas ${ }^{106}$ tomará un rumbo acelerado, aunque forzosamente tardío para la resolución del problema.

\section{III.1. EL PROCESO CONSTITUYENTE}

En este contexto, el Gobierno español procederá a publicar una serie de Decretos con fecha 25 de noviembre de 1897, que supondrán la plena vigencia de la Constitución española de 1876, tanto en lo referente al Título I de la misma, como en lo referente a las libertades de imprenta, asociación, reunión como en el sistema electoral, que haría vigente en las islas la ley electoral española de 1890, que acompañarán a las Cartas autonómicas de la misma fecha.

Los decretos del 25 de noviembre, al igual que pasara con el de Ampliación de reformas de la ley de bases de 1895, no siguió el trámite previsto en el texto constitucional, por similares motivos a lo que acontecía en aquél momento, a lo que posiblemente hubiera que sumar la oposición de un gran sector de la población española, tanto de la clase política, que invocaba el quebrantamiento de la soberanía española, así como de la prensa más representativa, ${ }^{107}$ que como indica Trías Monge, ${ }^{108}$ transmitían el mensaje de que se pasaba un momento de vergüenza nacional, de tal forma, que se le habían concedido a las Antillas todas las ventajas y a España nada.

Al igual que hiciera Cánovas con la ampliación de Bases, Sagasta, publicará una amplia Exposición de Motivos del Real Decreto de 1897, referente a la Constitución autonómica de las Islas de Cuba y Puerto Rico, en la que hará referencia al procedimiento irregular seguido, "(...) Reconoce el gobierno francamente que para el éxito de su obra bubiera sido mejor la pública discusión en el Parlamento y el análisis de la opinión en la prensa, en la cátedra $y$ en el libro; pero no es culpa suya, como no lo fue del anterior Gobierno, si la angustia de las circunstancias le obliga a prescindir de tan preciosa garantía. Pero si el partido que boy sirve desde el Gobierno los intereses de la Corona y del país no vaciló un momento en aprobar en su día la iniciativa del partido conservador, ni en votarle la indemnidad que solicitó de las Cor-

nia del Cabo, ni de una autonomía teórica, se trata de una solución precisa y clara. Se trata de aplicar a Cuba y Puerto Rico el programa autonomista cubano" En AMBLARD A.; Notas coloniales. págs. 103-112. A Pérez \& Cía. Madrid 1904.

106 Sobre las tensas relaciones existentes con los Estados Unidos de Norteamérica véase PoRTER VILÁ, H Historia de Cuba en sus relaciones con Estados Unidos y España. Im. J. Montero. La Habana, 1939. Véase igualmente LAZCANO Y MAZÓ, A.M.. Las Constituciones de Cuba" op. cit., pág. 55 y ss; pág. 86-91; véase igualmente, TRÍAS MONGE, Historia constitucional de Puerto Rico" op. cit., págs. 104-108.

107 Véase especialmente "El Correo español", "El Tiempo", "La Época", y " El Nacional" en los días siguientes a la publicación de los Decretos.

108 TRÍAS MONGE, J. op. cit., pág. 110. 
tes, hoy, que las circunstancias agobian con mayor pesadumbre, derecho tiene a esperar que la opinión apruebe boy en su conducta y que mañana le absuelvan las Cortes. ${ }^{109}$ Por esta razón no vacila en arrostrar la responsabilidad e intenta poner inmediatamente en ejercicio y llevar a la práctica las soluciones que implica el presente decreto con la misma sinceridad con que lo ba formulado y redactado, ${ }^{110}$ alejando hasta la sospecha de que pudiera haber indecisión en su conducta o reservas en sus promesas. Que si el régimen bubiera de flaquear en la práctica por falta de buena fe en alguno, nunca será, tenemos orgullo en proclamarlo, por culpa de los hombres a quienes ante todo anima el noble deseo de pacificar la Patria. Con esto cree el Gobierno que ha dicho cuanto era indispensable para que se conociese la génesis, la inspiración y el carácter del proyecto que, estableciendo en Cuba y Puerto Rico el régimen autonómico, somete a. V.M. A los que están familiarizados con la lectura de la Constitución de la Monarquía no les ofrecerá seguramente gran dificultad la del proyecto, pues a su sistema orgánico a la distribución de sus títulos y hasta a su redacción se ha ajustado el Gobierno en cuanto le ha sido posible (...)".

En la amplia exposición de motivos, se explica la necesidad del Estatuto, al que denomina Constitución Autonómica, no obstante no sea consecuencia de un acto emanado de la soberanía de los pueblos antillanos ${ }^{111}$, que no se proclama en parte alguna del texto, ${ }^{112}$ sino de la de España ejercida a través de sus órganos constitucionales. ${ }^{113}$ En defensa del Estatuto y del principio de autonomía, así como de la seriedad de las intenciones del Gobierno, el Presidente del Consejo de Ministros manifestará: "Es esto tanto más necesario

109 No obstante, en la Exposición de Motivos, se abre la puerta a que las Cortes, en su momento puedan modificar la Carta, "Seguramente algo quedará por hacer y algo necesitará reformarse: ya lo irán demostrando a su tiempo la defensa y la censura que de sus disposiciones se bagan, y ya se irá aquilatando lo que la una y la otra tengan de fundado, permitiendo incorporar lo bueno en el proyecto y descartar lo que no responda a sus ideas fundamentales cuando llegue el momento de recibir las sanción de las Cortes".

110 Cabe resaltar que la redacción de la Carta Autonómica se llevó por el Gobierno con la mayor discreción, ya que de hecho, no existe borrador alguno del mismo, que se conozca, en archivos públicos o privados, incluido el del Consejo de Ministros.

111 En un intento de no presentar el texto autonómico no como un acto exclusivo del Gobierno, sino como consecuencia de petición concreta del pueblo antillano, Sagasta, en la exposición de motivos manifestará "(...) era condición esencial para lograr el propósito buscar ...una forma práctica e inteligible para el pueblo que por él habia de gobernarse, y la encontró el Gobierno en el programa de aquel partido insular, considerable por el número, pero más importante aún por la inteligencia y la constancia, cuyas predicciones, desde hace veinte años, han familiarizado al país cubano con el espiritu, los procedimientos y la trascendencia de la profunda innovación que están llamados a introducir en su vida política y social."

112 Cabe destacar igualmente, que tampoco el texto español de 1876 proclama la soberanía nacional, optando por la fórmula de soberanía compartida entre el Rey y las Cortes del Reino, (Preámbulo).

113 Como se indicó anteriormente la Carta Autonómica en el momento de su publicación no había sido votada en Cortes, sino que respondía a iniciativa del Consejo de Ministros y firmada por el Rey ( Regente, María Cristina). 
cuanto que la primera y más esencial condición de éxito en esta clase de reformas es la absoluta sinceridad del propósito. Con ella ha procedido el Gobierno a estudiar la mejor fórmula de Constitución autonómica para las Islas de Cuba y Puerto Rico, y de que la intención y los resultados han marchado de consuno, espera dar en estas observaciones demostración acabada. Propúsose, ante todo, sentar claramente el principio, desenvolverlo en toda su integridad y rodearlo de todas las garantías de éxito. Porque cuando se trata de confiar la dirección de sus negocios a los pueblos que han llegado a la edad viril, o no debe hablárseles de autonomía, o es preciso dársela completa, con la convicción de que se les coloca en el camino del bien, sin limitaciones o trabas fijas de la desconfianza y del recelo. O se fía la defensa de la nacionalidad a la represión y a la fuerza, o se entrega al consorcio de los efectos y de las tradiciones con los intereses, fortificando a medida que se desarrolla por las ventajas de gobierno que enseñe y evidencie a las colonias que bajo ningún otro les serían dado alcanzar mayor grado de bienestar, de seguridad y de importancia"...

Sobre el modelo de autonomía aplicable a los territorios americanos, el Presidente del Consejo insistiría en que no tenía su base en otros existentes en territorios pertenecientes a metrópolis europeas ${ }^{114}$, aunque no dejaba de reconocer una cierta influencia en el modelo que ahora presentaba, "(...) el proyecto no tiene nada de teórico, ni es imitación o copia de otras Constituciones coloniales, miradas con razón como modelo en la materia, pues aún cuando el Gobierno ha tenido muy presentes sus enseñanzas, entiende que las instituciones de pueblos que por su historia y por su raza difieren tanto del de Cuba, no pueden arraigar donde no tienen ni precedente, ni atmósfera ni aquella preparación que nace de la educación y de las creencias. Planteado así el problema, tratándose de dar una Constitución autonómica a un territorio español poblado por raza española y por España civilizado, la resolución de las ideas y con arreglo al programa que lleve ese nombre en Las Antillas, sin eliminar nada de su contenido, sin alterar sobre su espiritu, antes bien complementándolo, armonizándolo, dándole mayores garantías de estabilidad, cual corresponde al Gobierno de una Metrópoli que se siente atraida a implantarlo por la convicción de sus ventajas, por el anhelo de llevar la paz y el sosiego a tan preciados territorios y por la conciencia de sus responsabilidades, no sólo ante la colonia, sino también ante sus propios vastísimos intereses que el tiempo ba enlazado y tejido en la tupida red de los años.

114 Esencialmente pertenecientes al Imperio Británico, tales como los casos de Australia, El Cabo en Sudáfrica y fundamentalmente Canadá, que era el modelo exigido en varias ocasiones por Estados Unidos de Norteamérica, (Woodford, Sec de Estado). En PORTEL VILÁ, op. cit., pág. 326. 


\section{III.2. CARACTERÍSTICAS Y PRINCIPIOS DE LA CONSTITUCIÓN AUTONÓMICA ${ }^{115}$}

Como se proclama en el Preámbulo, se trata de una Carta Otorgada, "De acuerdo con el parecer de mi Consejo de Ministros: En nombre de mi Augusto bijo el Rey Don Alfonso XIII, y como Reina Regente del Reino, vengo en decre$\operatorname{tar}(\ldots)$.

No establece una soberanía diferenciada de la española, ni proclama derechos y libertades específicos para los habitantes de Cuba y Puerto Rico, en virtud, como ya se dijo anteriormente, de que eran de plena vigencia los proclamados en el texto español de 1876, como consecuencia de los decretos de acompañamiento de la Carta Autonómica. ${ }^{116}$

No cuenta con grandes enunciados políticos, aunque sí establece una clara división de los poderes en el ámbito de las islas, que tenía su base en el régimen político español vigente.

La Autonomía que se concede a los territorios antillanos españoles, a diferencia de la otorgada a otros territorios de posesión europea, no es solamente de carácter administrativo, sino que puede considerarse también de índole política, en cuanto que los órganos autonómicos podían asumir y ejecutar decisiones políticas propias y diferenciadas de las del Estado, así, el artículo 32, proclama que, "Las Cámaras Insulares tienen facultad para acordar sobre todos aquellos puntos que no bayan sido especial y taxativamente reservados a las Cortes del Reino o el Gobierno Central, según el presente Decreto o lo que en adelante se dispusiere, con arreglo a lo preceptuado en el Artículo 2 adicional." 117

115 Se trata de dos Cartas Autonómicas, una para Cuba y otra para Puerto Rico, sensiblemente similares, por lo que sólo nos referiremos a uno u otro caso, en virtud de que deban resaltarse las diferencias pertinentes. No obstante, en el epígrafe correspondiente se utiliza el término Constitución Autonómica por ser el mismo el más comúnmente utilizado por historiadores y politólogos dentro de este periodo histórico, tradición que se ha venido conservando, al menos en el caso de Puerto Rico, donde actualmente se sigue denominando Constitución de Puerto Rico al actual Estatuto otorgado por los Estados Unidos de Norteamérica.

116 La Carta Autonómica se refiere en todo momento a los habitantes de las Islas como "españoles", proclamando el Primer Decreto de 9 de noviembre de 1897, en su artículo $1^{\circ}$, que reproduce el $1^{\circ}$ de la Constitución de 1876: Son españoles: Primero. Las personas nacidas en territorio español. Segundo. Los hijos de padre o madre españoles, aunque hayan nacido fuera de España. Tercero. Los extranjeros que hayan obtenido carta de naturaleza. Cuarto. Los que sin ella hayan ganado vecindad en cualquier pueblo de la Monarquía. Así mismo en el citado Decreto se proclama "Los españoles residentes en las Antillas, gozarán en los mismos términos que los residentes en la Península de los derechos consignados en el Título I de la Constitución de la Monarquía y de las garantías con que rodean su ejercicio las leyes del Reino. La diferencia entre los españoles originarios de la metrópoli y de las Islas sólo se establece a modo de discriminación positiva, respecto a las condiciones de sufragio pasivo para la Cámara de Representantes, "para ser elegido representante se requiere ser español, de estado seglar, mayor de edad, gozar de todos los derechos civiles, ser nacido en la Isla de (Cuba, Puerto Rico, respectivamente) o llevar cuatro años de residencia en ella y no hallarse procesado criminalmente". (Artículo 12. C.A.).

117 El citado artículo, proclamaba, que "Una vez aprobada por las Cortes del Reino la presente Constitución para las Islas de Cuba y Puerto Rico, no podrá modificarse sino en virtud de una ley y a petición del Parlamento Insular". 
Así mismo, la Autonomía concedida a las Islas de Cuba y Puerto Rico, goza de autonomía normativa; pudiendo considerarse esta potestad normativa, una de las características de la autonomía política frente a la simple descentralización administrativa ${ }^{118}$ "(...) en este sentido, y sin que la enumeración suponga limitación de sus facultades, les corresponde estatuir sobre cuantas materias y asuntos incumben a los Ministerios de Gracia y Justicia, Gobernación, Hacienda y Fomento, en sus tres aspectos de Obras Públicas, Instrucción y Agricultura. Les corresponde además el conocimiento privativo de todos aquellos asuntos de indole puramente local que afecten principalmente al territorio colonial; y en este sentido podrán estatuir sobre la organización administrativa, sobre división territorial, provincial, municipal o judicial; sobre sanidad marítima o terrestre; sobre crédito público, bancos y sistema monetario. Estas facultades se entienden sin perjuicio de las que sobre las mismas materias correspondan, según las Leyes, al Poder Ejecutivo Colonial. ${ }^{119}$

Correspondía igualmente a los Parlamentos Insulares la elaboración de los reglamentos de aquellas leyes votadas por las Cortes del Reino que expresamente se le confíen. Destacando a este respecto, lo referente al proceso electoral, formación del censo, calificación de los electores y manera de ejercitar el sufragio, aunque sus disposiciones no podían afectar al derecho del ciudadano, según lo reconocido por la ley electoral. ${ }^{120}$

La autonomía financiera se proclama igualmente en la Constitución Autonómica, así el artículo 35, proclama: "Es facultad exclusiva del Parlamento Insular la formación del presupuesto local, tanto de gastos como de ingresos, y del de ingresos necesarios para cubrir la parte que a la Isla corresponda en el presupuesto nacional,. ${ }^{121} \mathrm{Al}$ efecto, el Gobernador General debía presentar a las Cámaras, antes del mes de enero de cada año, el presupuesto correspondiente al ejercicio siguiente, dividido en dos partes: 1. La primera contendrá los ingresos necesarios para cubrir los gastos de la soberanía, 2. La segunda, los gastos e ingresos propios de la administración colonial. Ninguna de las Cámaras podrá pasar a deliberar sobre el presupuesto colonial sin haber volado definitivamente la parte referente a los gastos de Soberanía ${ }^{122}$. Como consecuencia de la Autonomía financiera, la negociación de los tratados de comercio que afectasen a las Islas, bien se debieran a la iniciativa del Gobierno Insular, bien a la del Gobierno Central, ${ }^{123}$ se llevarían siempre por éste, auxiliado

118 Sobre el principio de Autonomía y características del mismo, véase GONZÁLEZ-TREVIJANO, P., - NÚÑEZ RIVERO, C., El Estado Autonómico. Principios, organización y competencias" págs. 68-85. ED. Universitas. Madrid, 1998.

119 Artículo 32.C.A.

120 Artículo 33.C.A.

121 Artículo 35.C.A.

122 Sin embargo, era a las Cortes del Reino, a quién correspondía determinar cuáles habían de considerarse por su naturaleza gastos obligatorios inherentes a la soberanía, y fijar, además, cada tres años su cuantía y los ingresos necesarios para cubrirlos, salvo siempre el derecho de las mismas Cortes para alterar esta disposición. Artículo 36. C. A.

123 En los tratados de comercio en cuya negociación no hubiere intervenido el Gobierno Insular, se le comunicarán en cuanto fueren leyes del Reino, a fin de que pueda en un periodo de tres meses declarar si desea o no adherirse a sus estipulaciones. Artículo 38.C.A. 
en ambos casos por delegados especiales debidamente autorizados por el Gobierno colonial, cuya conformidad con lo convenido se hará constar al presentarlos a las Cortes del Reino. ${ }^{124}$

El principio de Autonomía se extendía al ámbito provincial y local, aunque en este caso, ésta se agotaba en la autonomía administrativa y financiera; al frente de cada provincia existía una Diputación, elegida en la forma que determinaran los Estatutos coloniales y compuesta por un número de personas proporcional a su población. ${ }^{125} \mathrm{Al}$ igual que se disponía en la legislación preautonómica, la Diputación Provincial tenía un funcionamiento autónomo en todo lo referente a la creación y dotación de establecimientos de instrucción pública, servicio de beneficencia, vías provinciales terrestres, fluviales o marítimas, formación de los presupuestos y nombramiento y separación de los empleados. ${ }^{126}$ Así mismo, tanto los Municipios como las Provincias tenían autonomía financiera para establecer libremente los ingresos necesarios para cubrir sus presupuestos, sin otra limitación que la de hacerlos compatibles con el sistema tributario general de la isla. ${ }^{127}$

\section{III.3. ORganOS DE LA CONSTITUCiÓN AUTONÓMICA}

El artículo 2 de la Carta proclamaba que "el Gobierno de cada una de las Islas se compondrá de un Parlamento Insular, dividido en dos Cámaras y de un Gobernador General, representante de la metrópoli, que ejercerá en nombre de ésta la Autoridad Suprema".

\section{III.3.1. El parlamento insular}

El título II, "De las Cámaras Insulares", en su artículo 3, proclama que "La facultad de legislar sobre los asuntos coloniales en la forma y en los términos marcados por las Leyes corresponde a las Cámaras Insulares con el Gobernador General", que reproduce comparativamente y en términos similares lo dispuesto en el artículo 18 de la Constitución española de 1876 "La potestad de hacer las leyes reside en las Cortes con el Rey".

La Carta Autonómica, siguiendo la pauta marcada por el constitucionalismo español y en concreto por el texto de $1876,{ }^{128}$ estable el bicameralismo: Cámara de Representantes y Consejo de Administración", contando ambas Cá-

124 Artículo 37.C.A.

125 Artículo 53 C.A

126 Artículo 54 C.A

127 Artículo 55 C.A. En todo caso, en la C. A. se proclamaba en su artículo 62, que ningún Estatuto colonial podía privar a los Municipios ni a la Diputación de su autonomía.

128 En la historia constitucional española hasta el momento, sólo el texto de1812 estableció el monocameralismo. 
maras con iguales facultades, ${ }^{129}$ de tal forma, que como proclama el artículo 23 de la Constitución Autonómica, "Para que una resolución se entienda votada por el parlamento Insular será preciso que haya sido aprobada en iguales términos por la Cámara de Representantes y por el Consejo de Administración". ${ }^{130}$

Las Cámaras debían reunirse todos los años, sin que pudieran sesionar juntas, ${ }^{131}$ correspondiendo al Rey, y en su nombre al Gobernador General, ${ }^{132}$ convocarlas, así como suspender, cerrar sus sesiones; la disolución de las mismas podía hacerse de forma separada o simultánea, con la obligación de convocarlas de nuevo o de renovarlas dentro de tres meses; ${ }^{133}$ no obstante, en la Carta Autonómica, al igual que en el Texto Constitucional español de 1876, no se indicaba fecha concreta en la que debía hacerse la convocatoria.

No podía estar reunida una de las cámaras, sin que lo estuviera también la otra, ${ }^{134}$ Las sesiones debían ser públicas, aunque en los casos que exijan reserva podrá cada una celebrar sesión secreta.,135

Correspondía a las Cámaras Insulares, además de la potestad legislativa colonial: 1. Recibir al Gobernador General el juramento de guardar la Constitución y las leyes que garantizan la autonomía de la Colonia; 2. Hacer efectiva la responsabilidad de los Secretarios del Despacho, los cuales, cuando sean acusados por la Cámara de Representantes, serán juzgados por el Consejo de Administración; 3. Dirigirse al Gobierno Central por medio del Gobernador General para proponerle la derogación o modificación de las leyes del Reino vigentes, para invitarle a presentar proyectos de Ley sobre determinados asuntos o para pedirle resoluciones de carácter ejecutivo en los que interesen a la Colonia. ${ }^{136}$

Las Cámaras gozaban de autonomía interna en su funcionamiento, contando a tal efecto, con un Reglamento cada una de ellas, elaborada por ellas mismas; ${ }^{137}$ así mismo, serán las propias Cámaras las que se encarguen de la

129 En este aspecto, se sigue igualmente el modelo de la Constitución de 1876, que proclama, que los dos cuerpos colegisladores, Senado y Congreso de los Diputados cuenten con iguales facultades. (Artículo 19. C.E.)

130 No obstante, los Estatutos coloniales sobre contribuciones y crédito público se presentarán primero a la Cámara de Representantes. (Artículo 21.C.A.), de forma similar a lo proclamado en el artículo 42 de la C.E.

131 Artículo 19.C.A.

132 Tampoco podían reunirse en presencia del gobernador General; en este punto, la Constitución Autonómica seguía la pauta marcada por el artículo 39, de la C.E., que impedía que los Cuerpos Colegisladores de la Nación deliberaran juntos, ni en presencia del Rey.

133 Artículo 15.C.A. En este punto se seguía la pauta marcada por el artículo 32 de la C.E.

134 Salvo en el caso en que el Consejo de Administración ejerza funciones judiciales. Artículo 18. C.A.

135 Artículo 19.C.A.

136 Artículo 29. C.A.

137 En ausencia de Reglamento, en el momento de aprobarse la Constitución Autonómica, el artículo 16, disponía que la Cámara de Representantes y el Consejo de Administración se regirían por los respectivos Reglamentos del Congreso de Diputados y el Senado de la Nación. 
verificación de poderes de los miembros parlamentarios. ${ }^{138}$ Así como de elegir entre sus miembros al Presidente, Vicepresidentes y Secretarios de entre sus miembros. ${ }^{139}$

Los parlamentarios gozaban de inmunidad e inviolabilidad ${ }^{140}$ "Los Consejeros de Administración y los individuos de la Cámara de Representantes son inviolables por sus opiniones y votos en el ejercicio de su cargo", ${ }^{141}$ "Los Consejeros de Administración no podrán ser procesados ni arrestados sin previa resolución del Consejo, sino cuando sean hallados in fraganti o cuando aquél no esté reunido; pero en todo caso se dará cuenta a este Cuerpo lo más pronto posible para que determine lo que corresponda. Tampoco podrán los Representantes ser procesados ni arrestados durante las sesiones sin permiso de la Cámara, a no ser hallados in fraganti; pero en este caso, y en el de ser procesados o arrestados cuando estuvieren cerradas las Cámaras, se dará cuenta lo más pronto posible a la de Representantes para su conocimiento y resolución. La Audiencia pretorial de La Habana conocerá de las causas criminales contra los Consejeros y Representantes en los casos y en la forma que determinen los Estatutos Coloniales. ${ }^{142-143}$

\section{III.3.2. El Consejo de Administración}

El Consejo de Administración se componía de quince miembros, de los cuáles, ocho eran electos y siete designados por el Rey, en el caso de la Isla de Puerto Rico, y de treinta y cinto miembros en el caso de la Isla de Cuba, de los cuales dieciocho eran electos, y los otros diecisiete designados por el Rey. ${ }^{144}$

Para tomar asiento en el Consejo de Administración se requería: 1. Ser español; 2. Haber cumplido treinta y cinco años; 3. Haber nacido en la Isla o llevar en ella cuatro años de residencia constante; 4 . No estar procesado criminalmente; 5 . Hallarse en la plenitud de los derechos políticos; No tener sus bienes intervenidos y no tener participación en contratos con el Gobierno Central o con el de la Isla. Los accionistas de las Sociedades Anónimas no se considerarán contratistas del Gobierno, aun cuando lo sean las Sociedades a que pertenezcan. ${ }^{145}$

138 Artículo 16. C.A.

139 Artículo 17. C.A.

140 Sobre este punto, se sigue al pie de la letra lo proclamado en los artículos 46 y 47 de la Constitución española de 1876, salvo en lo dispuesto a las causas que anulan dichas garantías, según lo proclamado en el artículo 27. C.A.

141 Artículo 25. C.A

142 Artículo 26. C.A

143 Las garantías consignadas en el Artículo anterior no se aplicarán a los casos en que el Consejero o Representante se declare autor de artículos, libros, folletos, impresos de cualquier clase en los cuales se invite o provoque a la sedición militar, se injurie o calumnie al Gobernador General o se ataque la integridad nacional. Artículo 27. C.A.

144 A su nombre eran elegidos por el Gobernador General. Artículo 5. C.A.

145 Artículo 6.C.A. 
Además en el caso de Puerto Rico se exigía que contara con dos años de antelación, una renta propia anual de 4000 pesos, exigencia que no se manifiesta en los mismo términos en la Constitución Autonómica de Cuba, ya que en este caso, sólo se indica que podrán ser elegidos o designados Consejeros de Administración los que posean con dos años de antelación renta propia anual de dos mil pesos, procedentes de bienes inmuebles que radiquen en la Isla. ${ }^{146}$

Además, podían ser elegidos o designados consejeros de administración los que junto a las condiciones señaladas en el artículo anteriormente citado, cumplieran alguna de las siguientes condiciones:

Puerto Rico. 1.- Ser o haber sido Senador del Reino o tener las condiciones que para ejercer dicho cargo señala el Título III de la Constitución. ${ }^{147} 2$.Haber desempeñado durante dos años alguno de los cargos que a continuación se expresan: 1. Presidente o Fiscal de la Audiencia territorial de Puerto Rico. 2. Director del Instituto de San Juan. 3. Consejero de administración del antiguo Consejo de este nombre. 4. Presidente de las Cámaras de Comercio de la capital y de Ponce. 5. Presidente de la Sociedad Económica de Amigos del País de Puerto Rico. 6. Presidente de la Asociación de Agricultores. 7. Decano del Ilustre Colegio de Abogados de la capital. 8. Alcalde de San Juan o Presidente de la Diputación provincial durante dos bienios. 9. Deán del Cabildo catedral. 3.- Podrán ser igualmente elegidos o designados los propietarios que figuren en la lista de los 50 mayores contribuyentes por territorial o en la de los 50 primeros por comercio, profesiones, industria y artes. ${ }^{148} \mathrm{~b}$ ) Cuba. 1. Poseer con dos años de antelación renta propia anual de dos mil pesos, procedente de bienes inmuebles que radiquen en la Isla; 2 . Ser o haber sido Senador del Reino o tener las condiciones que para ejercer dicha cargo señala el Título III de la Constitución: a) Presidente del Consejo de Secretarios del Despacho; b) Presidente o Fiscal de la Audiencia de La Habana; c) Rector de la Universidad de la misma; d) Consejero de Administración del antiguo Consejo de este nombre; e) Presidente de la Cámara de Comercio de la capital; f) Presidente de la Sociedad Económica de Amigos del País, de La Habana; g) Presidente del Círculo de Hacendados; h) Presidente de la Unión de Fabricantes de Tabacos; i) Presidente de la Liga de Comerciantes, Industriales y Agricultores de Cuba; j) Presidente de la Academia de Ciencias de La Habana; k) Decano del Ilustre Colegio de Abogados de la capital; 1) Alcalde de La Habana, si el Ayuntamiento procediere de elección popular. m) Presidente de Diputación Provincial, si ésta fuera de elección popular; n) Deán de cualquiera de los Cabildos catedrales; 3. Podrán igualmente ser elegidos o designados los que figuren en las listas de los cincuenta mayores contribuyentes por territorial o en la de los cincuenta primeros por comercio, profesiones, industria y artes.

146 Artículo 7 C.A. de Cuba.

147 Artículo 22 de la Constitución Española de 1876.

148 Artículo .C.A. de Puerto Rico. 
No obstante, las condiciones necesarias para ser nombrado o elegido Consejero de Administración, podían variarse por una ley del Reino, a petición o propuesta de las Cámaras insulares. ${ }^{149}$

El texto constitucional no especifica régimen de incompatibilidades alguno, salvo el ya referido de no tener participación en contratos con el Gobierno central de la isla, ${ }^{150}$ así como tampoco poder admitir empleo, ascenso que no sea de escala cerrada, título ni condecoración mientras estuviesen abiertas las sesiones; pero tanto el Gobierno local como el central podían conferirles, dentro de sus respectivos empleos o categorías, las comisiones que exija el servicio público; " ${ }^{151}$ pudiendo los Consejeros ser Secretarios de Despacho.

Los Consejeros nombrados por la Corona, lo eran de por vida, ${ }^{152}$ debiendo hacerse su nombramiento por decreto especial, en el que figure el título, en que dicho nombramiento se funda.

Los Consejeros electivos se renovarán por mitad cada cinco años, y en totalidad cuando el Gobernador General disuelva el Consejo de Administración. ${ }^{153}$

\section{III.3.3. La Cámara de Representantes}

La Cámara de Representantes se componía, en virtud de un representante por cada veinticinco mil habitantes, según nombramiento de las juntas electorales, en la forma que determinara la ley. ${ }^{154}$

Para ser elegido representante se precisaba reunir los siguientes requisitos $^{155}$ : Ser español; Tener estado seglar; Mayoría de edad; Gozar de todos los derechos civiles; Ser nacido en la Isla, o llevar cuatro años de residencia en ella; No hallarse procesado criminalmente. ${ }^{156}$

$\mathrm{Al}$ igual que en el texto constitucional español, la Carta Autonómica no determina con qué clase de funciones es incompatible el cargo de Representante y los casos de reelección ${ }^{157}$, dejando dicha determinación a la Cámara Insular; ${ }^{158}$ en todo caso, se perdía la condición de representante si a quienes el Gobierno Central o el local concedieran pensión, empleo, ascenso que no

149 Artículo 9. C.A. en este punto se sigue la pauta marcada por el artículo 23 de la constitución española de 1876.

150 Artículo 6.C. A.

151Artículo 10.C.A

152 Tiene su base en el artículo 20.1 a de la Constitución Española de 1876.

153 Artículo 8.C.A Tiene su base en el artículo 24 de la Constitución Española de 1878.

154 Artículo 11.C.A.

155 Los requerimientos para el cargo eran los mismos, salvo la condición de residencia, que los dispuestos en el artículo 29 de la Constitución Española de 1876.

156 Artículo 12.C.A.

157 Artículo 13 C.A. y artículo 29 de la Constitución Española de 1876.

158 En la Constitución española se hacía referencia a que la ley determinará (art. 29). 
sea de escala cerrada, comisión con sueldo, honores o condecoraciones, no participaran a la Cámara la renuncia de la gracia en los quince días siguientes a la concesión. ${ }^{159}$ Los representantes podían ser nombrados Secretarios de Despacho.

El mandato de los Representantes lo era por cinco años y podían ser reelegidos indefinidamente. ${ }^{160}$

\section{III.3.4. El Gobernador General}

El Gobernador General ostentaba el gobierno supremo de la Isla, era nombrado por el Rey, a propuesta del Consejo de Ministros; juraba el cargo ante el Rey. Ejercía como vice-real patrono las facultades inherentes al Patronato de Indias; teniendo el mando superior de todas las fuerzas armadas de mar y tierra existentes en la Isla; era delegado de los Ministerios de Estado, Guerra, Marina y Ultramar, estándole subordinadas todas las demás autoridades de la Isla y era responsable de la conservación del orden y de la seguridad de la Colonia. ${ }^{161}$

Era el representante de la Nación y le correspondían las siguientes funciones:

Como representante de la Metrópoli. 1. Designar libremente los empleados de su Secretaría; 2. Publicar, ejecutar y hacer que se ejecuten en la Isla las leyes, decretos, tratados, convenios internacionales y demás disposiciones emanadas del Poder legislativo, así como los decretos, reales órdenes y demás disposiciones emanadas del Poder Ejecutivo y que le fueran comunicados por los Ministerios de que es delegado. Cuando a su juicio y al de sus Secretarios del Despacho las resoluciones del Gobierno de Su Majestad pudieran causar daños a los intereses generales de la Nación o a los especiales de la Isla, suspenderán su publicación y cumplimiento, dando cuenta de ello y de las causas que motiven su resolución al Ministerio respectivo; 3 . Ejercer la gracia de indulto a nombre del Rey, dentro de los límites que especialmente se le hayan señalado en sus instrucciones, y suspender las ejecuciones de pena capital cuando la gravedad de las circunstancias lo exigiesen o la urgencia no diere lugar a solicitar y obtener de Su Majestad el indulto, oyendo en todo caso el parecer de sus Secretarios del Despacho; 4. Suspender las garantías expresadas en los Artículos 4, 5, 6 y 9 y párrafos primero, segundo y tercero del Artículo 13 de la Constitución del Estado; aplicar la legislación de orden público y tomar cuantas medidas crea necesarias para conservar la paz en el interior y la seguridad en el exterior del territorio que le está confiado, oyendo previamente al Consejo de Secretarios; 5 . Cuidar de que en la Colonia se administre

159 Artículo 14.C.A. 1876.

160 Artículo 13.C.A. tiene su base en los artículos 28 y 30 de la Constitución española de

161 Artículo 41.C.A. 
pronta y cumplidamente la justicia, que se administrará siempre en nombre del Rey; 6. Comunicar directamente sobre negocios de política exterior con los Representantes, Agentes Diplomáticos y Cónsules de España en América. La correspondencia de este género se comunicará íntegra y simultáneamente al Ministro de Estado. ${ }^{162}$

Como autoridad superior de la Isla y Jefe de la Administración: 1. Cuidar de que sean respetados y amparados los derechos, facultades y privilegios reconocidos o que en adelante se reconozcan a la Administración Colonial; 2. Sancionar y publicar los acuerdos del Parlamento insular, los cuales les serán sometidos respectivamente por el Presidente y Secretarios de las Cámaras respectivas. Cuando el Gobernador General entienda que un acuerdo del Parlamento Insular extralimita sus facultades, atenta a los derechos de los ciudadanos reconocidos en el Título Primero de la Constitución o a las garantías que para su ejercicio les han señalado las leyes, o compromete los intereses de la Colonia o del Estado, remitirá el acuerdo al Consejo de Ministros del Reino, el cual, en un período que no excederá de dos meses, lo aprobará o devolverá al Gobernador General, exponiendo los motivos que tenga para oponerse a su sanción y promulgación. El Parlamento Insular, en vista de estas razones, podrá volver a deliberar sobre el asunto y modificarle, si así lo estima conveniente, sin necesidad de proposición especial. Si transcurrieran dos meses sin que el Gobierno Central hubiera manifestado opinión sobre un acuerdo de las Cámaras que le hubiere sido transmitido por el Gobernador General, éste procederá a su sanción y promulgación; 3. Nombrar, suspender y separar a los empleados de la Administración Colonial a propuesta de los respectivos Secretarios del Despacho y con sujeción a las Leyes; 4. Nombrar y separar libremente los Secretarios del Despacho. ${ }^{163}$

El Gobernador General contaba con la asistencia de cinco Secretarías de Despacho: ${ }^{164}$ a) Gracia, Justicia y Gobernación, b) Hacienda, c) Instrucción Pública, d) Obras Públicas y Comunicaciones, y d) Agricultura, Industria y Comercio. $^{165}$

Las Secretarías de Despacho, aunque no conformaban órgano colegiado, contaban con un Presidente, que era designado por el Gobernador General de entre sus miembros. ${ }^{166}$

Los Secretarios de Despacho debían refrendar los mandatos del Gobernador General, ${ }^{167}$ aunque debía exceptuarse de este precepto en los siguientes casos: 1. Cuando se trata de la remisión al Gobierno de los acuerdos de las Cámaras insulares, especialmente cuando entienda que en ellos se atenta a

162 Artículo 42.C.A.

163 Artículo 43.C.A.

164 El aumento o disminución de las Secretarías del Despacho, así como la determinación de los asuntos que a cada una correspondiese, pertenecía al Parlamento Insular.

165 Artículo 45.C.A.

166 A su vez, éste Presidente podía designar a otro Presidente, sin departamento determinado.

167 Artículo 44 C.A. 
los derechos garantizados en el Título Primero de la Constitución de la Monarquía o a las garantías que para su ejercicio han señalado las leyes; 2 . Cuando haya de ponerse en ejecución la Ley de Orden Público, sobre todo si no hubiere tiempo o manera de comunicarlo al Gobierno Central; 3. Cuando se trate de la ejecución y cumplimiento de leyes del Reino sancionadas por $\mathrm{Su}$ Majestad y extensivas a todo el territorio español o al de su Gobierno. ${ }^{168}$

Los Secretarios de Despacho eran responsables de sus actos ante las Cámaras Insulares ${ }^{169}$ pudiendo tomar parte en las discusiones de ambos cuerpos, aunque sólo podían votar en uno de ellos, en el caso de pertenecer al mismo. ${ }^{170}$

\section{III.3.5. La Justicia}

Aún cuando las leyes relativas a la Administración de Justicia, de la organización de los Tribunales son de carácter general y obligatorias, por tanto, para las Islas, el Parlamento insular podía, con sujeción a ellas, dictar las reglas y proponer al Gobierno Central las medidas que facilitaran el ingreso, conservación y ascenso en los Tribunales locales de los naturales de la Isla, o de los que en ella ejercieran la profesión de Abogados. ${ }^{171}$

Los conflictos de jurisdicción entre las diferentes asambleas municipales, provinciales e insular, o con el Poder Ejecutivo, que por su índole no fueran referidas al Gobierno Central, se sometían a los Tribunales de Justicia. ${ }^{172}$ Asî mismo, si surgiera alguna cuestión de jurisdicción entre el Parlamento insular y el Gobernador General en su calidad de representante del poder central, que, a petición del primero, no fuera sometida al Consejo de Ministros del Reino, cada una de las dos partes podrá someterla a la resolución del Tribunal Supremo del Reino, que resolverá en pleno y en una sola instancia. ${ }^{173}$

El Tribunal Supremo conocerá en única instancia de las responsabilidades definidas en el Código Penal que se imputaren al Gobernador General. ${ }^{174}$ De las causas criminales contra los consejeros o Representantes, conocían las Audiencias territoriales de La Habana y Puerto Rico, respectivamente. ${ }^{175}$

La escasa vigencia de las Cartas Autonómicas en virtud de la guerra hispano-americana, impiden que pueda hacerse un riguroso análisis sobre la exacta adecuación de las mismas a la España americana. El proceso constituyente fue largo e inacabado, pues las Constituciones Autonómicas se procla-

168 Artículo 51. C.A.

169 Artículo 47. C.A.

170 Artículo 46.C.A.

171 Artículo 34.C.A.

172 Artículo 31.C.A.

173 Artículo 67. C.A.

174 Artículo 50. C.A. De las responsabilidades administrativas en que incurriera conocía el Consejo de Ministros.

175 Artículo 26. C.A. 
maron sin haber sido votadas en las Cortes y sin el necesario consenso, ni peninsular ni antillano, para los primeros, porque consideraban que la Autonomía era el abandono de las Antillas, como dicen manifestó la Reina Regente Da María Cristina, cuando el Presidente del Consejo de Ministros Sagasta le puso el Real Decreto a la firma, "Dicen que con la autonomía se perderá Cuba", a lo que Sagasta contestó:; Ay, Señora! ¡Más perdida que está! ${ }^{176}$ Para los otros, los españoles de América, la norma llegaba tarde, demasiado tarde, casi un siglo después de que los constituyentes gaditanos proclamaran la igualdad de los españoles de ambos hemisferios y que desde 1837 había quedado en el olvido, esperando la "ley especial" que nunca llegó.

TitLE: The Autonomous Letters of Cuba and Puerto Rico: first precedent of the Autonomy State.

ABSTRACT: The descentralizing desires of Cuba and Puerto Rico were demostrated for the first time in the origins of the constitutional Spanish State, specially in the constituent processes of 1812 and 1836. Later, fron the second half of the XIX century, to the same ones will join the aim of an administrative and political autonomy, specially in case of Cuba. The response of the Spanish State, always late, will lead to Autonomous Letters that will know their publication when the development of the events make an impossible solution. Anyway, such a statutory grant or of "Autonomous Constitution" will supose the first precedent of the above mentioned model regarding organization of the State, the only original aspect of the spanish constitutionalism.

RESUMEN: Los deseos descentralizadores de Cuba y Puerto Rico se manifiestan por primera vez en los origenes del Estado Constitucional español, especialmente en los procesos constituyentes de 1812 y 1836; posteriormente, a partir de la segunda mitad del siglo XIX, a los mismos se unirá el objetivo de una autonomía administrativa y política, especialmente en el caso de Cuba. La respuesta del Estado español, tardía siempre, se manifestará mediante las Cartas Autonómicas que conocerán su publicación cuando ya el desarrollo de los acontecimientos hagan inviable dicha solución. No obstante, tal otorgamiento Estatutario o de "Constitución Autonómica", supondrá el primer antecedente de dicho modelo de organización territorial del Estado y acaso, el único aspecto originario del constitucionalismo español.

Key Words: Constitution, Statute, Autonomic Constitution, Base law, descentralization.

Palabras clave: Constitución, Estatuto, Constitución Autonómica, Ley de Bases, Descentralización.

176 En AMBLARD, op, ant, cit., pág. 33. 